\title{
ASYMMETRIC MONETARY TRANSMISSION IN EMU: THE ROBUSTNESS OF VAR CONCLUSIONS AND CECCHETTI's LEGAL FAMILY THEORY
}

\author{
ADAM ELBOURNE \\ JAKOB DE HAAN \\ CESIFO WORKING PAPER No. 1327 \\ CATEGORY 6: MONETARY POLICY AND INTERNATIONAL FINANCE \\ NOVEMBER 2004 \\ - from the CESifo website: www.CESifo.de
}




\title{
ASYMMETRIC MONETARY TRANSMISSION IN EMU: THE ROBUSTNESS OF VAR CONCLUSIONS AND CECCHETTI's LEGAL FAMILY THEORY
}

\begin{abstract}
We review studies on monetary transmission in the EU countries using the VAR approach and analyse why they often lead to divergent outcomes. Firstly, we estimate 43 VAR models across ten EU countries and compare the robustness of the ranking of the magnitudes of the price and output responses. The main specification differences between the VAR models are the use of two different sample periods; the inclusion of additional variables; and the use of recursive, long run, and structural identification schemes. Secondly, we calculate rank correlations between the output and price responses of a recursive VAR and a structural VAR to the financial structure indicators used by Cecchetti (1999), who argued that legal systems cause financial structure, which in turn causes asymmetric transmission. In contrast to Cecchetti, we find that there is little correlation.
\end{abstract}

JEL Code: E52.

Keywords: monetary transmission, VAR models, EMU.

Adam Elbourne

University of Groningen

Faculty of Economics

PO Box 800

9700AV Groningen

The Netherlands

a.elbourne@eco.rug.nl
Jakob de Haan

University of Groningen

Faculty of Economics

PO Box 800

9700AV Groningen

The Netherlands

j.de.haan@eco.rug.nl 


\section{Introduction}

For the first time since the Roman Empire, a large portion of Europe now shares a common currency. Since the start of the Economic and Monetary Union (EMU) in Europe at the beginning of 1999, the European Central Bank (ECB) has been responsible for monetary policy in Europe; however, the impact of these policy decisions may differ across euro zone countries. The existing empirical evidence does not give a clear picture of how important these differences actually are, or if they even exist.

At least four modelling strategies have been attempted (OECD, 1999) in this line of literature:

- simulating existing macroeconomic (single or multi-country) models;

- using small structural models;

- employing reduced form equations;

- testing policies with structural Vector Autoregression (VAR) models.

Differences in modelling strategies are likely to lead to differences in outcomes. However, even within the same 'class' of models conclusions often differ substantially.

The first purpose of this paper is to review studies using the VAR approach and to analyse why they often lead to divergent outcomes. The reason for selecting the VAR class of models is that there is no requirement to split between exogenous and endogenous variables. It is also a relatively free format that can be modelled similarly for each country. Modern econometric methods can also be used to cope with long run restrictions if that is required. We look at various models encompassing these differences.

One commonly cited study is Cecchetti (1999), who concludes upon the evidence of a VAR model that there are differences in monetary transmission across European Union countries and that these differences are caused by differing financial structures. In his view, the different financial structures are caused by the legal traditions of the countries, English common law, French civil law, Scandinavian law, and German law. Given the perceived differences in estimates across studies, this may not be a robust conclusion. The second purpose of this paper is therefore to examine to what extent Cecchetti's results are driven by the selection of one particular VAR model. 
The remainder of the paper is organised as follows. Section 2 summarises VAR studies focusing on differences in monetary transmission across EU countries. Only studies with estimates for at least three European countries are included in our review. This is a little ad hoc but allows for concentration on more comparable studies. Section 3 presents the outcomes of 43 VAR models. Section 4 re-examines the conclusions of Cecchetti in light of our study of the robustness of VAR estimates. The final section offers some concluding comments.

\section{VAR Studies: An overview}

\section{Modelling choices}

The original VAR models as proposed by Sims (1980) were an alternative to large scale macro-econometric models and do not rely on "incredible" identifying assumptions. VAR models have subsequently been widely used for monetary analysis as table 1 shows. ${ }^{1}$ A brief look at table 1 should be enough to make the reader question the robustness of VAR conclusions. In this section we will discuss the VAR modelling process before going on to discuss the conclusions and modelling differences of the studies summarized in table 1.

In VAR modelling there are many choices that need to be made regarding the specification of the model, all of which have the potential to alter the estimated responses and hence, alter any conclusion regarding asymmetric transmission across countries. ${ }^{2}$ We now proceed with a basic step-by-step guide to the VAR modelling procedure.

Before estimating a model for cross country analysis the countries taken up in the sample have to be chosen. On this point the more the better - the number of countries will not change the results for each individual country but it may change the overall conclusion regarding the significance of any asymmetries in transmission. After choosing the countries of interest one first estimates the reduced form as a vector autoregression as in equation $1 .^{3}$

\footnotetext{
${ }^{1}$ Table 1 only shows some studies that look at multiple countries. The use of VAR models for single country analysis is even more widespread.

${ }^{2}$ For example, Cochrane (1998) finds that output responses can vary a lot as one changes identifying assumptions.

${ }^{3}$ For simplicity of exposition we only show endogenous variables in the equations.
} 


$$
y_{t}=A(L) y_{t}+u_{t}
$$

where $y_{t}$ is the vector of endogenous variables, $A(L)$ is a lag polynomial of order $p$, and $u_{t}$ is a vector of reduced form errors. At this stage 3 choices need to be made. Firstly, which variables are going to be included? Secondly, what is the sample period going to be? And finally, how many lags should be included? ${ }^{4}$ We will analyse the issue of how many variables should be included below when we discuss the identification of the model; here it will suffice to note that the larger and more complicated a VAR model becomes, the more parameters in the $A(L)$ matrices need to be estimated and the more degrees of freedom are used.

There is also a trade-off over the sample period: the longer a sample period is, the more degrees of freedom available for estimation, but the greater the problem with parameter constancy. In an ideal world, there would be a long sample period that is a single regime. But the actual world isn't ideal: governments change and even when they don't their policy regimes do. ${ }^{5}$ More degrees of freedom can be gained by choosing to employ monthly instead of quarterly data. But, many series are not available at a monthly frequency, chief among these being GDP; industrial production is then usually employed as a proxy. ${ }^{6}$

The choice of an appropriate lag length is also important because a time series study has only a limited number of degrees of freedom with which to work. The lag length has to be sufficiently great to make the residuals white noise, which may not be compatible with the limited degrees of freedom available. Small differences in the response for each individual country may add up to much greater uncertainty when looking for differences in transmission between countries.

After estimating the reduced form VAR we would like to be able to discuss the impact of changes in one variable on another. We cannot, however, simply change one of the elements of $u_{t}$ and see what happens because the errors in $u_{t}$ are correlated

\footnotetext{
${ }^{4}$ That is the dimension of the vector $y$, the number of sample points, $T$, and the order of $A(L), p$.

${ }^{5}$ For example, the exchange rate regime of the UK has changed frequently over the past 30 years.

${ }^{6}$ However, some techniques in VAR modelling rely on long run economic theory where the actual time in years is of more importance than the number of observations available. For example, Lothian and Taylor (1996) show that a unit root can only be rejected for the dollar-sterling real exchange rate if a sample period of around 100 years is used, regardless of the sampling frequency of the exchange rate series.
} 
with each other. We need to identify the underlying orthogonal shocks, $e_{t}$, as shown in equation 2 in moving average form.

$$
B(L) y_{t}=e_{t}
$$

where $B(L)$ is an infinite order lag polynomial. The relationship between the reduced form model and the structural model are shown in the next four equations.

$$
\begin{aligned}
& e_{t}=B_{0} u_{t} \\
& B(L)=B_{0}+B^{0}(L) \\
& A(L)=-B_{0}^{-1} B^{0}(L) \\
& \Sigma=B_{0}^{-1} \Lambda B_{0}^{-1}
\end{aligned}
$$

Equation 3 shows that the structural shocks are derived from their reduced form counterparts through the $B_{0}$ matrix: the contemporaneous correlation matrix from the structural moving average representation. This does not imply that only contemporaneous restrictions can be imposed because long run restrictions can be imposed through (non-linear) restrictions on the $B_{0}$ matrix. Equation 4 splits the infinite order lag polynomial from the structural form into the contemporaneous correlations, $B_{0}$, and the lagged correlations. Equation 5 maps each reduced form coefficient matrix onto its structural form counterpart. This can be done simply if the researcher knows the $B_{0}$ matrix of contemporaneous correlations. $B_{0}$ is identified through the unrestricted covariance matrix of the reduced form, $\Sigma$, and the diagonal covariance matrix of the structural form, $\Lambda$, as in equation 6 . This, unfortunately, does not uniquely identify $B_{0}$ - there are many matrices that satisfy equation 6 . To go from the reduced form initially estimated as a $\operatorname{VAR}(p)$ to the structural form wherein the impulse responses have a meaningful interpretation, one has to impose $\mathrm{n}^{2}$ identifying restrictions. $n(n+1) / 2$ restrictions are imposed by making the covariance matrix of the residuals, $\Lambda$, an identity matrix. This leaves $n(n-1) / 2$ to be imposed elsewhere in the system. In a VAR with only four variables, six extra restrictions (over and above those imposed by the identity matrix for the residuals) are needed; it is easy to see that a larger VAR runs the risk of falling foul of Sims (1980) incredible restrictions criticism. One of the most commonly used identification strategies is the Cholesky 
decomposition shown for a four variable system of prices, $P$, output, $Y$, interest rates, $i$, and an exchange rate, $E$, in equation 7 .

$$
\left[\begin{array}{c}
e_{P} \\
e_{Y} \\
e_{i} \\
e_{E}
\end{array}\right]=\left[\begin{array}{cccc}
1 & 0 & 0 & 0 \\
b_{21} & 1 & 0 & 0 \\
b_{31} & b_{32} & 1 & 0 \\
b_{41} & b_{42} & b_{43} & 1
\end{array}\right]\left[\begin{array}{c}
u_{P} \\
u_{Y} \\
u_{i} \\
u_{E}
\end{array}\right]
$$

The six restrictions here are represented by the zero elements above the diagonal. This is in itself a theoretical restriction of the error structure because each variable responds contemporaneously to some variables but not to others and is ordered in the system. Taking the third row we can discuss what this means for the interest rate. Due to the distribution of the zero elements we can see that the interest rate responds contemporaneously to the underlying price and output shocks, but not to the exchange rate shocks. The flip side of this strategy, shown by the third column, is that prices and output do not respond contemporaneously to interest rate shocks whilst the exchange rate does. This means that the variables follow a causal ordering: prices, output, the interest rate, and the exchange rate. For the system as a whole this causal ordering is a very strong restriction.

The system does not need to be identified as a whole; it can be partially identified. Partial identification relies solely on identifying a reaction function for monetary policy; the remaining shocks are left unidentified. ${ }^{7}$ As shown by Christiano, Eichenbaum and Evans (1999), the ordering of variables in the interest rate equation is the only important identification criterion if one is only concerned with monetary policy. Within the variables that are ordered before the interest rate equation the order makes no difference to estimated responses to a monetary policy shock. For example, in the system shown in equation 7 it makes no difference if prices or output innovations are at the top of the $e_{t}$ vector, only whether they are above or below the interest rate. This allows the researcher to only consider the ordering of the interest rate variable, thus reducing considerably the number of identifying restrictions required. That those variables contemporaneously affected by interest rate shocks do not enter the interest rate feedback rule and those that don't react contemporaneously

\footnotetext{
${ }^{7}$ The other structural shocks have no economic meaning and the analysis of responses to the shocks is meaningless.
} 
do enter the rule is still quite restrictive. McCallum (1999) argues that a policy rule should not include the current price level or output because these are not observable; the data are only published with a lag. This cannot be combined with the belief that monetary policy only has a lagged effect with a Cholesky decomposition.

Another potential source of identifying restrictions is the use of long run restrictions as pioneered by Blanchard and Quah (1989). A long run restriction usually takes the form that a shock to one variable has no long run impact on another. For example, if monetary neutrality holds, monetary shocks should have no long run effect on output. Long run restrictions are equivalent to setting a zero restrictions on the $B_{1}$ matrix, which in turn is equivalent to a non-linear constraint on the $B_{0}$ matrix. Although Blanchard and Quah only had a two variable VAR of output and unemployment their technique has been extended and used in the analysis of monetary policy.

So far we have said nothing about the properties of the individual time series. A common finding for macroeconomic variables is that they are integrated. ${ }^{8}$ Regressing one integrated variable on another can lead to spurious regressions, a commonly used example being the finding that rainfall causes inflation. The unit roots cannot be ignored: either the series can be differenced to remove the unit roots, or, if present in the system, cointegration can be utilised. If a linear combination of two (or more) series that are integrated of order one ${ }^{9}$ is not integrated, the series are said to be cointegrated. Cointegration can be tested for with the Johansen technique. If there is evidence of cointegration it is a useful source of the extra restrictions required to move to the structural form. The cointegrating vector needs to be chosen from the data or it can be selected for a priori reasons. ${ }^{10}$ If the cointegrating relationship is selected for a priori reasons it must be tested to see if this is an appropriate restriction. The number of restrictions that can be gleaned through cointegrating relationships is less than the $n(n-1) / 2$ required for identification, so other restrictions are still needed. Sims, Stock and Watson (1990) show, however, that if enough of the variables are cointegrated then an analysis in levels is still correct because the ordinary least squares estimator (OLS) of the reduced form (equation 1) efficiently estimates the cointegrating relationship anyway.

\footnotetext{
${ }^{8}$ That is, one or more of the roots of the lag polynomial lie outside the unit circle.

${ }^{9}$ Series that are integrated of order 1 need to be differenced once to be made stationary.

${ }^{10}$ An a priori reason could come from something like a money demand equation.
} 
Effectively there are 3 modelling choices at this stage: 1) difference any integrated time series until they are stationary, 2) estimate the model in error correction format, thereby specifically taking account of any cointegration, or 3) estimate by OLS and rely on the Sims, Stock and Watson result.

Even if the same VAR model has been estimated, there can still be discrepancies arising from the particular impulse responses that are employed. The two different impulses that are widely used are the one unit shock and the one standard deviation shock. The shapes of any impulse responses created by these two different shocks are the same because one is just a linear transformation of the other. The magnitudes of the responses will differ, however. Where the standard deviations of shocks are different across countries this modelling choice will affect the appearance of asymmetric transmission. It makes more sense to compare all the countries using a standard 100 basis points impulse as it will be a common policy change across all countries. However, in the sample period under consideration a 100 basis points shock was not observed in the countries in our sample, which may make this shock fall foul of the Lucas critique.

\section{Digression on the price puzzle}

A common finding of VAR research into the monetary transmission mechanism is that a rise in interest rates leads to an increase in the price level. This counter intuitive phenomenon has been dubbed the 'price puzzle'. Its seriousness is a matter of debate: either the price responses alone are meaningless but the other responses are reliable, or there is something wrong that casts serious doubt about all of the estimates from the model if prices do not respond as theory suggests. For example, Ramaswamy and Sloek (1997), by focusing solely on the output responses to monetary shocks, inherently assume that the price puzzle does not invalidate conclusions about the real effects of monetary policy. ${ }^{11}$ Giordani (2004) shows that a VAR model with a price puzzle overestimates the output responses; he is one of many authors who argue that the presence of the price puzzle renders the other responses meaningless.

The occurrence of the price puzzle is usually attributed to a failure to identify actual shocks to interest rates. If inflation is expected to rise in the future a central bank will raise interest rates to try to arrest the increase in inflation. A model that

\footnotetext{
${ }^{11}$ Our replications of the Ramaswamy and Sloek model have generated price puzzles.
} 
doesn't capture this expected increase in inflation will exhibit the price puzzle because the endogenous response of the central bank to higher expected inflation will be treated as a shock when it is no such thing. Using equation 7 to illustrate this point, the endogenous response of interest rates to expected inflation is not captured by $b_{31}$ or $b_{32}$ (or by the lag structure), instead it forms part of $e_{i}$. The model is misspecified because it does not take account of the forward looking nature of monetary policy. ${ }^{12}$ Sims pioneered the use of commodity prices acting as an information variable - the oil price, for example, has a forward looking component and can be used to predict inflation. The inclusion of the oil price for the US is generally successful in removing the endogenous part of monetary policy from the identified shocks of a VAR model.

Other authors have suggested other causes. Giordani (2004) attributes the price puzzle to the exclusion of a measure of the output gap. Theoretical models of the transmission mechanism relate inflation to the position of an economy in the business cycle: in a recession there is little upward pressure on prices because firms have plenty of spare capacity so an interest rate reduction will be less inflationary in a recession than in a boom. Giordani uses data generated from a New Keynesian model of the economy to show that a VAR without a proxy for the output gap will generate a price puzzle even when the data comes from a model with the normal price response. He also shows that the identified VAR model will give larger (and therefore incorrect) estimates of the other responses. One should not believe the responses from a VAR model that displays the price puzzle according to this critique. Giordani also claims that the solution employing commodity prices is due to the fact that commodity prices vary cyclically with the US business cycle. Hence, including commodity prices works for US models because they approximate the output gap, not because they have a predictive ability for inflation per se.

Hanson (2004) also dismisses the forecasting inflation story by showing that those variables that are the best at predicting inflation are not the most successful at removing the price puzzle. He claims that the price puzzle is due to estimating VAR models over multiple regimes so that two (or more) interest rate setting feedback rules have to be approximated by one equation. The shocks from the estimated equation do not tally with the actual shocks for either regime. He suggests that carefully selecting the sample period can remove the price puzzle.

\footnotetext{
${ }^{12}$ However, the correct signs for the responses are insufficient to claim that the model is correctly
} 
The monetary policy of small open economies is widely seen as being highly dependent on external factors. Hence many authors (see Kim and Roubini 2000, for example) have suggested that without the nominal exchange rate the feedback rule for a small open economy will be misspecified, and likely to result in the price puzzle. Other authors have argued that European countries have followed German monetary policy so that monetary shocks are easier to identify if one also includes the German interest rate in the model (see Ehrmann 2000, for example).

\section{VAR findings}

Table 1 shows a summary of 11 VAR studies. ${ }^{13}$ All of the papers consider the three largest EU countries: France, Germany, and the UK. Individual country studies are, by their nature, not focused on the question of asymmetric transmission of policy in Europe, hence we limit ourselves to those that are.

Table 1 here

The first point to make is that the various studies come to differing conclusions despite the common VAR methodology. Out of the 11 papers considered, only the studies of Gerlach and Smets (1995), Kieler and Saarenheimo (1998), Mojon and Peersman (2002) conclude that there is little or no difference in the transmission of monetary shocks across countries. Unfortunately, the other studies disagree about the nature of the differences between countries. For instance, Ramaswamy and Sloek (1997) find that there are two groupings of countries: in Austria, Belgium, Finland, Germany, the Netherlands, and the UK, the effects of monetary policy take longer to be felt and have greater magnitude. Philipsen and Wuyts (1999) also conclude that there are two different groups; however, the two studies do not have the same countries in each of the groups.

Barran, Coudert and Mojon (1996) conclude that the lags of the responses are fairly similar but the magnitudes are not. Their ordering of the responses is correlated to a degree with the groupings of Ramaswamy and Sloek, although their conclusion about the timing is not. Dedola and Lippi (2004) conclude that Germany is affected

\footnotetext{
specified.

${ }^{13}$ Whilst attempting to detail the differences between VAR models that have been used and their differing conclusions, table 1 is not intended to be an exhaustive list of all multi country VAR studies.
} 
more by a monetary shock than France or the UK; Italy is somewhere in between. Ehrmann (2000), in direct contrast to Dedola and Lippi, finds that the UK is much more sensitive to an interest rate shock than the other countries. Ehrmann also finds great variation across the other countries. Altavilla (2000) also concludes that there are differences between the countries. Again, there are two groupings and once again they don't match the groupings of the other studies.

Clements, Kontolemis and Levy (2001) also find differences and like Ramaswamy and Sloek they find that Austria, Germany and the Netherlands have a relatively greater response to monetary shocks. However, they do not conclude that there are 2 distinct groups. Furthermore, they report that Finland has one of the smallest responses, while Ramaswamy and Sloek found it to have one of the largest. Kim and Roubini (2000) conclude that there are differences in monetary transmission among the countries considered: Germany has the largest response; France, Italy and the UK have a smaller response.

Whilst all studies summarised in table 1 find that the policy response in Germany is relatively large, the conclusions for the other countries diverge considerably. In light of the modelling discussion above we shall now look at some of the differences between the studies.

Kieler and Saarenheimo, Gerlach and Smets, and Kim and Roubini only include the 4 largest European countries (Kieler and Saarenheimo just the largest 3); the first two of these constitute two-thirds of the studies concluding that there is little or no difference. At the other extreme are Ehrmann and Philipsen and Wuyts who include 13 countries and conclude that there are differences.

The dimension of the VAR systems also varies widely. Four of the studies considered here use only three variables. At the other extreme are Kim and Roubini, who use 7. Four studies also use a different number of variables for each country, evidently in an attempt to better describe the reaction function of each central bank.

There are also a wide range of sample periods studied. Philipsen and Wuyts choose the longest period at 27 years from 1972 to 1998. Ehrmann and Gerlach and Smets, go for a relatively short sample of 15 years. Ehrmann's choice is clearly an attempt to avoid estimating across different regimes by choosing to start the sample period only after the frequent exchange rate parity alterations that occurred within the European Monetary System prior to 1983. Philipsen and Wuyts choose to go for more sample points. 
Most of the studies considered here do not discuss the lag length issue. Philipsen and Wuyts and Ramaswamy and Sloek report that they use the Akaike Information Criteria (AIC) to choose lag length; many of the other studies are silent on this issue. As mentioned above, more lags may need more sample points, which can be obtained by using monthly data. However, eight of the eleven studies use data at a quarterly frequency including the one with the smallest time span, Gerlach and Smets. The study with the longest time span, Philipsen and Wuyts, uses monthly data. They state that this is not only to increase the number of observations, but also to make their contemporaneous restrictions more appropriate. ${ }^{14}$

There is also a split among the studies when it comes to the treatment of unit roots. Ramaswamy and Sloek, Kieler and Saarenheimo, and Kim and Roubini are among those that use their variables in levels even though they conclude that the variables are integrated. At the other extreme, Ehrmann and Altavilla estimate the models using the cointegration that is present. None of the studies difference the time series to achieve stationarity.

The most commonly used identification strategy is the Cholesky decomposition. Studies employing this approach include Ramaswamy and Sloek, Philipsen and Wuyts, and Barran, Coudert, and Mojon. Gerlach and Smets use long run restrictions assuming that a monetary shock has no long run effect on GDP and also a similar restriction for a demand shock. These two shocks are distinguished by assuming that the monetary shock has no contemporaneous effect on GDP. Kim and Roubini use a set of (non recursive) contemporaneous restrictions based upon a model of maximising agents suggested by Sims and Zha (1995).

Although Ehrmann uses the short term German interest rate in some of the models for countries other than Germany, he does not treat it as an exogenous variable. Whilst the Bundesbank set monetary policy with regard only to the German macroeconomic situation (and hence one would expect, for example, Italian price developments to have no effect on the Bundesbank's policy), the authors here make little use of exogenous variables. Also Mojon and Peersman include the German interest rate endogenously into their models for the other countries. Kim and Roubini include oil prices and US interest rates endogenously in their models for European

\footnotetext{
${ }^{14}$ Clearly, a no contemporaneous reaction restriction is more likely to be valid within one month than within one quarter.
} 
countries, when one would have thought these could also have been used exogenously.

Philipsen and Wuyts and Kim and Roubini use a one standard deviation shock; the conclusions of these studies may not be the same when a common 100 basis points shock is used. Ramswamy and Sloek are among the other studies that use a standardised 100 basis points shock.

\section{VAR models}

The 43 VAR models that we estimated here follow these and other modelling suggestions so that the VARs chosen here are either used or suggested in the literature for the study of the transmission mechanism. They therefore seem to be good candidates to test the robustness of VAR conclusions regarding the asymmetrical transmission of monetary policy across Europe. A detailed description of the models is given in table 2. Data sources are shown in table 3.

Tables 2 and 3 here

The basic model is a three variable VAR estimated either quarterly with real GDP, prices and a short term interest rate, or monthly with industrial production instead of real GDP. The basic model is identified using the Cholesky decomposition. As such, the quarterly model is very similar to the specification of Ramaswamy and Sloek; the monthly model is akin to the Philipsen and Wuyts model. Two different sample periods were used: 1973-98 and 1980-98. The latter sample period was chosen to avoid the volatility of the 1970 s. This model was also estimated in first differences and in terms of the yearly inflation rate and the HP filtered output gap. We then added more variables to the system. We added the German short term interest rate, ${ }^{15}$ then the oil price as exogenous variables. Following this, we estimated the basic model with a fourth endogenous variable added: either money or the nominal effective exchange rate. We also estimated the models with different identification schemes. We have also included a model with long run restrictions in the style of Blanchard and Quah,

\footnotetext{
${ }^{15}$ In the case of Germany we used the US Fed Funds rate.
} 
one estimated as a VECM with cointegration imposed according to the Johansen procedure, and one estimated using the identification scheme of Kim and Roubini, although the US variables by Kim and Roubini have been replaced by their German counterparts for the non-German countries.

After calculating the impulse responses to a 100 basis points shock in each model we calculate four summary statistics for the responses of both output and prices: the peak negative effect, the timing of the peak and the sum of the effects over the first three and five years. We use these statistics to look at the robustness of the results, especially the cross country aspects, to the changes in model specification.

Figure 1 here

Figure 1 shows the results of Pearson's correlation statistic between the methods for the peak effect on prices across countries. We chose the Pearson statistic over rank correlation statistics because the models all purport to be showing the same thing, hence the magnitudes should be similar across models and not just the rankings. Furthermore, the Pearson statistic allows the rankings to change among countries with very similar estimates without causing a dramatic fall in the correlation statistic. In figure 1 , a significant positive correlation at the $1 \%$ level is coloured black, at the $5 \%$ level grey; a negative correlation is represented by a minus sign. Insignificant positive correlations are left blank. With this representation of the results it is easy to judge the overall robustness of the results by the colour of the figure: a very robust result would be very dark and have no minus signs. The estimates of the peak price response are clearly not robust. The first column of table 4 also shows this clearly; the mean correlation of the peak price responses is only 0.17 .

Table 4 here

Figure 2 shows that the results are even less robust for the timing of the peak; there are very few significantly positive correlations and many negative correlations. The mean correlation from table 4 is only 0.16 .

Figure 2 here 
Figure 3 shows slightly more robustness among the quarterly recursive and the monthly recursive VARs for the sum over 60 months of the inflation responses. The rectangle of white and negative entries in figure 3 shows that there is no correlation between monthly and quarterly models, however. The mean correlation across all models of the 60 month sum of price responses is just 0.05 . It may be tempting to treat all positive estimates for the sum as zero, in effect applying the prior belief that a positive interest rate shock does not cause prices to raise. If this is done the mean correlation rises to 0.08 as shown in the fourth column of table 4 . We can do the correlation analysis again and exclude all non-negative results: this gives us column 5 . The mean correlation of 0.17 is still very low, especially when one realises how few negative estimates there are for each model; only a very high correlation would be statistically significant with such few observations. ${ }^{16}$ We also looked to see if summing over a shorter horizon improved matters. As can be seen from the last column of table 4 , it did not.

Figure 4 shows that there is greater robustness for the peak output effect, especially among the quarterly models, than was the case for price responses. As with prices there is no correlation among the timing of the peak effects and this is shown in figure 5. Figure 6 shows that the summed output loss is robust across the recursive models; the bands of insignificant correlations among the non-recursive models are striking.

Figure 4 here

Table 5 is the counterpart of table 4 for the correlation between the output results. One can see that the output responses are more robust than the price responses with mean correlations of 0.59 and 0.32 for the peak effect and the 60 month sum, respectively. Treating the positive sums as zero improves the mean correlation to 0.49 ; leaving them out of the analysis altogether improves thing still further to 0.66. Choosing to look at the sum over 36 months makes little difference.

Table 5 here

\footnotetext{
${ }^{16}$ With 3 observations the one-sided 5\% critical value for the Pearson statistic is 0.805 .
} 
If we look at the two rows for the quarterly models with industrial production in figures 4 and 6 , we can see that there is little correlation between these and the quarterly models with GDP. We can therefore conclude that choosing industrial production as a proxy for GDP is not a sound strategy for investigating asymmetric transmission.

Two further hypotheses can be investigated with our results: Firstly, are the results robust for the models using the common Cholesky recursive identification? Secondly, are they robust across models that successfully remove the price puzzle? These issues are shown in tables 6 and 7. The price puzzle was so prevalent that, in order to include a meaningful number of models for table 7 , we had to choose the relatively low hurdle of 5 or more negative sums for both price and output responses for inclusion into the analysis. Even this low hurdle left us with only 11 models out of the original $43 .^{17}$

Table 6 here

Restricting ourselves to the recursive VARs does not improve the robustness of the peak price response with the mean correlation falling from 0.17 to 0.16 . The mean 60 month sum correlation rises from 0.05 to 0.17 but remains very low. The output results are more robust across the subset of recursive VARs, though. The mean correlations for the peak and the 60 month sum rise from 0.59 and 0.32 to 0.81 and 0.81 .

The mean correlations for the non-price-puzzle models show an increase in the robustness of the peak price response but not of the sum of price responses. The mean correlation for the output measures is lower between the non-price-puzzle models than across all of the models. We can conclude that choosing the non-price-puzzle subset does not improve the robustness of the results.

Table 7 here

\footnotetext{
${ }^{17}$ The VARs that had five or less price puzzles as defined by a negative sum of price effects over 60 months for the ten countries are as follows: Q80, Q731D, Q80GEIR, Q80IRD, Q80IRDV, M73ПG, M80IRD, M73IRDV, M80IRDV, and KRM80.
} 


\section{Financial Structure}

In various recent studies it has been claimed that asymmetries in monetary policy transmission in the euro area may result from differences in financial structure. An often cited study is Cecchetti (1999), who bases his view on the lending view of monetary policy transmission, according to which monetary policy actions change the reserves available to the banking system, thereby affecting the willingness of banks to lend, and ultimately, the supply of loans.

The theoretical foundation of the lending view focuses on the intermediation role of banks and capital market imperfections (see e.g. Bernanke and Gertler, 1995). The lending view has two parts, one that focuses on the balance sheet of borrowers and a second that focuses on bank loans.

Monetary policy actions may affect firms' net worth. By decreasing expected future sales, a deflationary monetary policy may decrease the firm's net worth. Or the monetary hike may reduce the price of equity. A third way in which restrictive monetary policy may affect the balance sheet of firms is through the general price level: an unanticipated decline in the price level increases the value of firms' liabilities in real terms. No matter what causes the decline in net worth, it will have important consequences. The lower the firm's net worth the more severe the adverse selection and moral hazard problems are in lending to this firm. This, in turn, will restrict external financing.

As far as the bank loans channel is concerned, it has been pointed out that some firms (notably small ones) are dependent on banks for finance. A reduction in the quantity of reserves forces a reduction in the level of deposits, which should be matched by a fall in loans. When loans and bonds are imperfect substitutes on the balance sheets of banks, a rise of the interest rate resulting in a liquidity squeeze may reduce the amount of bank loans.

The weaker a country's banking system, the stronger the expected impact of policy movements (Cecchetti, 1999). Monetary policy actions affect the reserves of the banks, thereby affecting their willingness to lend. How this will affect individual firms depends on the alternative financing methods available to them. Firms that can borrow in the bond market or issue equity will be less affected by contractions in bank loans than firms that rely entirely on bank financing. 
Cecchetti (1999) relates the estimates of the impact of monetary policy on output and inflation of Ehrmann (1998) ${ }^{18}$ to an overall indicator for financial structure reflecting the presence of small banks, the health of the banking system, and firms' possibilities for direct capital market access. Cecchetti concludes that there is a clear relationship between the estimated strength of monetary policy and the overall indicator for financial structure. Countries with many small banks, less healthy banking systems, and poorer direct capital market access display a greater sensitivity to monetary policy changes than do countries with big, healthy banks and deep, welldeveloped capital markets. Cecchetti's financial structure statistics cover banking industry and bank health statistics along with statistics for alternative sources of finance.

Cecchetti combines the financial structure indicators into three summary statistics: one for the importance of small banks, one for bank health, and one for the availability of alternative finance. His summary statistic for each factor is a number between 1 and 3 based on a subjective weighting of the underlying statistics. This is then further combined into a predicted policy effectiveness indicator by averaging the scores for small banks, bank health, and alternative finance. The resulting indciators for the various countries are then further averaged into four legal families and compared to the VAR responses.

We chose two of the VAR models that we estimated and compare their outcomes with the financial structure indicators reported in Cecchetti (1999). Instead of using a summary statistic, we examine whether there are significant relationships in the underlying data. Absence of such a relationship suggests that Cecchetti's conclusion may be dependent upon the aggregation of the statistics. To this end we use Kendall's rank tests between the summary statistics for the Q80 and KRM80 models. We chose these models because the first is a representative recursive model that doesn't suffer too much from the price puzzle and the second is the most successful at resolving the price puzzle across all countries.

Table 8 here

\footnotetext{
${ }^{18}$ This is the working paper version of Ehrmann (2000).
} 
Table 8 shows the Kendall's rank correlations between the summary statistics from the Q80 model and Cecchetti's financial structure indicators. ${ }^{19}$ Since price and output responses to a positive interest rate shock should be negative, a positive correlation means that a large value of a Cecchetti indicator is associated with a small response. The only significant results for the banking industry indicators are a negative correlation with the timing of the peak price response and a positive correlation with the sum over 36 months (but not over 60 months). There are no statistically significant results for the output responses. However, if we look at the correlation between Cecchetti's overall statistic for the importance of small banks and the output response statistics we get a very different picture: more small banks is correlated significantly with a smaller output response at the 5\% level. Theory predicts the opposite: smaller banks are more likely to contract their loan supply following an interest rate hike.

There is only one significant correlation for bank health when using the underlying statistics; a higher average Thompson rating is associated with a larger fall of prices over 36 months (but again, not over 60 months). Again, theory would suggest the opposite: healthier banks should be better able to shield their customers from interest rate shocks.

There are no significant correlations for the price response with the external finance statistics. For output there are some: greater reliance on equity finance as measured by both market capitalisation and the proportion of all external finance provided by bank loans is associated with larger output losses which also display greater peak magnitudes. Again this is counter to the credit channel theory: greater availability of external finance should insulate firms from contractions in bank loan supply. Conversely, the summary statistic for the importance of external finance has a positive (in line with theory) correlation with the peak response and sums for output, although this is not statistically significant. This is despite the opposite relationship being significant in the underlying statistics. ${ }^{20}$

\footnotetext{
${ }^{19} \mathrm{We}$ ignore the uncertainty surrounding the central forecasts for the impulse responses. If we were to take this uncertainty into consideration the correlations given here would be less significant. Since we find little or no correlation when we overestimate the significance of the results, it does not affect our conclusion that there is no evidence to conclude that there is relationship between VAR outcomes and financial structure by overstating the significance of the evidence presented here.

${ }^{20}$ We also calculated Spearman's rank correlations, which gave even an even lower number of statistically significant results.
} 
Cecchetti also looks at rights afforded to shareholders and to creditors and gives them a score. He also includes a variable to quantify the enforcement of these rights. For the recursive model we find no correlation for either prices or output with shareholder rights. We also find no correlation between creditor rights and the price responses. For output we find a positive correlation between creditor rights and both the peak output reponse and the 60 month sum (again, there is a difference if we sum over 36 months). Strangely, we find a negative correlation between the enforcement of these rights and the output responses.

We would also expect to see Cecchetti's overall predicted effectiveness of monetary policy statistic to be correlated with the responses at an individual country level if the 'legal structure causes financial structure causes asymmetric transmission' theory were true. The only significant relation that we found is that the peak impact of a shock on output occurs earlier if policy is expected to be effective. Whilst this is in line with theory one should bare in mind the almost random nature of the timing statistics discussed in section 3 above. If we chose a different VAR model the timing of the peak output responses is very different and this relationship will not hold. This can be seen, for example, in the correlations for the KRM80 model in table 9.

Table 9 here

If we now focus on table 9, which shows the same correlations calculated for the structural VAR KRM80 we can see even less associations with the underlying indicators. The only statistically significant correlations are negative relationship between the amount of corporate debt and the timing of the peak output response and between predominance of bank loans and the timing of the peak inflation effect (both in line with theory). Overall, we would have expected more significant results than this even if with no underlying relationship. In total there are 16 indicators correlated with 6 summary statistics (counting the two different sums as one separate statistic) giving a total of 96 correlations. With no underlying relationships we would expect to find 4.8 significant relations. We only find two. ${ }^{21}$

\footnotetext{
${ }^{21}$ We have also calculated the correlations for other VARs. If one takes the Q80IRDV model that is similar to the model used by Cecchetti, there are more significant correlations, although many are of opposite sign to that predicted by theory. For example, small banks are significantly correlated with smaller peak output responses at the $1 \%$ level even though theory suggests the opposite; furthermore, there is no correlation with the underlying statistics used to value the importance of small banks. If one
} 
Cecchetti's next step is to group the countries into their legal families and look at the correlation between the average VAR statistic and the average predicted effectiveness for each legal family. The results of a comparable analysis for our two representative models are shown in table 10 . Given that we have found virtually no correlation between our VAR outcomes and the statistics at the country level it is quite surprising to find that the results from the KRM80 model are highly correlated with the predicted effectiveness at the legal family level. The correlations are even of the correct sign: a higher predicted effectiveness of monetary policy is correlated with greater price reductions and greater output losses. ${ }^{22}$ If the legal structure causing financial structure causing asymmetric transmission structure were true, we would expect to see evidence of this at the individual country level. With our results, we do not see a relationship between transmission magnitudes and financial structure indicators at the country level. Only when we aggregate to the legal family level do we find a correlation in line with Cecchetti's theory and only for the KRM80 model, not the Q80 model. ${ }^{23}$ This suggests that the result is merely due to aggregation.

Table 10 here

\section{Conclusion}

We estimated 43 VAR models to see if VAR based conclusions about asymmetric transmission of monetary policy in Europe are robust across different model specifications. The estimated responses of output are robust across the recursive models but this doesn't extend to those models which are less susceptible to the price puzzle. The price responses are not robust. The claim that the price puzzle is of no concern when discussing the real effects of monetary policy shocks is wrong, because we have shown that using a model specification to that does not give rise to the price

looks at the estimates reported by Cecchetti, there are instances when there is correlation with a summary indicator, for example availability of alternative finance and the timing of the price response, but not with any of the individual external finance availability statistics. Once again, we see that choosing different VARs gives different significant correlations. More details of correlations for other VARs available on request.

${ }^{22}$ We don't pay too much attention to the significance level of these results because we have only 4 observations.

${ }^{23}$ Given the lack of robustness among the VAR responses the conclusion that legal structure causes asymmetric transmission clearly relies heavily on which VAR model is chosen. 
puzzle changes the output responses so much that there is no correlation between the estimates of recursive models displaying the price puzzle and those that do not. The suggested remedies for the price puzzle in recursive VARs are not uniformly successful across countries; perhaps this should come as no surprise given that countries are different and their inflation processes may also be different.

The model that was most successful in removing the price puzzle was the 7 variable SVAR of Kim and Roubini (2000), which estimated a negative response of prices for all countries. This is in sharp contrast to the recursive models.

We further demonstrate that the result and conclusion of Cecchetti (1999) is not robust across model specifications. In this regard we side with Angeloni, Kashyap, Mojon and Terlizzese (2001), who conclude that there do not appear to be asymmetries in transmission that are robust across different VAR specifications, let alone with other modelling strategies. A representative recursive model and the SVAR model of Kim and Roubini often had correlations of opposite signs with the financial structure indicators given by Cecchetti. Moreover, the picture painted by the correlation analysis differed sometimes between the underlying indicators and the condensed summary indicators. Whilst there is no correlation between the predicted effectiveness of monetary policy and the summary statistics from the 2 VAR models when analysed on a country-by-country basis, one appears for one of the VAR models when the countries are grouped into legal families for the SVAR model. This suggests that the result of Cecchetti may be the result of aggregating too far.

\section{References}

Altavilla, C., (2000), "Measuring monetary policy asymmetries across EMU countries”, CES Discussion Paper 00.22, Katholieke Universiteit Leuven.

Angeloni, I., A. Kashyap, B. Mojon and D. Terlizzese (2001), "Monetary transmission in the Euro area: Where do we stand?", ECB Working Paper No. 114.

Barran, F., V. Coudert, and B. Mojon (1996), "The transmission mechanism of monetary policy in European countries", CEPII Working Paper 9603. 
Bernanke, B.S. and M. Gertler (1995), "Inside the Black Box: The Credit Channel of Monetary Policy Transmission”, Journal of Economic Perspectives, 9 (4), 27 48 .

Blanchard, O. J. and D. Quah (1989), “The Dynamic Effects of Aggregate Demand and Supply Disturbances", American Economic Review, 79 (4) pp. 655-73.

Cecchetti, S., (1999), "Legal structure, financial structure, and the monetary transmission mechanism", Federal Reserve Bank of New York Economic Policy Review, 9-28.

Christiano, L., M. Eichenbaum and C. Evans, (1999), "Monetary Policy Shocks: What Have We Learned, and To What End", in J.B.Taylor and M. Woodford (eds.), Handbook of Macro Economics, Amsterdam: North Holland.

Clements, B., Z. Kontolemis, and J. Levy (2001), "Monetary policy under EMU: Differences in transmission mechanism?", IMF Working Paper.

Cochrane, J. (1998), "What do the VARs Mean?: Measuring the Output Effects of Monetary Policy", Journal of Monetary Economics, 41 (2), 277-300.

Dedola, L., and F. Lippi, (2004), "The monetary transmission mechanism: evidence from the industries of five OECD countries", forthcoming in: European Economic Review.

Ehrmann, M., (1998), “Will EMU generate asymmetry? Comparing monetary policy transmission across European countries", EUI Working Paper, ECO No. $98 / 28$.

Ehrmann, M., (2000), “Comparing Monetary Policy Transmission across European Countries", Weltwirtschalftliches Archiv, 136 (1), 58-83.

Gerlach, S. and F. Smets, (1995), “The monetary transmission mechanism: evidence from the G-7 countries", in: BIS, Financial Structure and the Monetary Policy Transmission Mechanism, Basle: BIS, 188-224.

Giordani, P. (2004), “An Alternative Explanation of the Price Puzzle”, forthcoming in: Journal of Monetary Economics.

Hanson, M. S., (2004), “The 'Price Puzzle' Reconsidered”, forthcoming in: Journal of Monetary Economics.

Kieler, M. and T. Saarenheimo, (1998), "Differences in monetary policy transmission? A case not closed", European Commission Economic Papers, No. 132. 
Kim, S. and N. Roubini (2000), "Exchange rate anomalies in the industrial countries: A solution with a structural VAR approach", Journal of Monetary Economics, $45,561-586$.

Lothian, J. R. and M. P. Taylor (1996), "Real Exchange Rate Behavior: The Recent Float from the Perspective of the Past Two Centuries," Journal of Political Economy, 104, 3, 488-509.

McCallum, B. T (1999), "Issues in the Design of Monetary Policy Rules". In J. Taylor and M. Woodford (eds.), Handbook of Macroeconomics, Amsterdam: NorthHolland.

Mojon, B. and G. Peersman (2002), “A VAR description of the effects of monetary policy in the individual countries of the euro area", ECB Working Paper, No. 92.

OECD (1999), EMU Facts, Challenges and Policies, Paris: OECD

Philipsen, C, and G. Wuyts, (1999), "Monetaire versus reële convergentie in Europa", Centrum voor Economische Studiën, Leuven.

Ramaswamy, R. and T. Sloek, (1997), "The real effects of monetary policy in the European Union: what are the differences?" IMF Working Paper, No WP/97/160.

Sims, C., (1980), "Macroeconomics and reality", Econometrica, 48, 1-48.

Sims, C., J. Stock, and M. Watson (1990), "Inference in linear time series models with some unit roots", Econometrica, 58, 113-144.

Sims, C. and T. Zha (1995), "Does monetary policy generate recessions?" Yale University, Working Paper. 


\section{Table 1. Multi-country VAR Studies: A Summary}

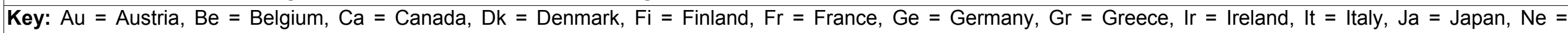

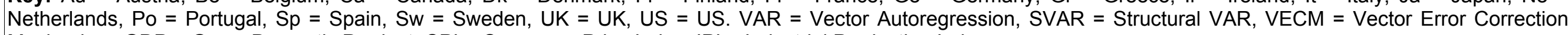
Mechanism, GDP = Gross Domestic Product, CPI = Consumer Price Index, IPI = Industrial Production Index.

\begin{tabular}{|c|c|c|c|c|c|c|}
\hline Study & Countries & Type & Variables & Estimation Period & Model & Conclusion \\
\hline Gerlach \& Smets (1995) & $\begin{array}{l}\mathrm{Ca}, \mathrm{Fr}, \\
\text { Ge, It, Ja, } \\
\text { UK, \& US. }\end{array}$ & SVAR & \begin{tabular}{|l|} 
3. Real GDP, CPI, \\
3 month money \\
market/ treasury \\
bill rate
\end{tabular} & $\begin{array}{l}\text { 1979-1993 } \\
\text { Quarterly }\end{array}$ & $\begin{array}{l}\text { Three identifying restrictions: No long run } \\
\text { effects of monetary shocks on real GDP. No } \\
\text { long run effects of demand shocks on real } \\
\text { GDP. No contemporaneous effect of monetary } \\
\text { policy. }\end{array}$ & $\begin{array}{l}\text { Little evidence of large differences } \\
\text { in transmission between } \\
\text { countries, esp when } \mathrm{Cl} \text { are } \\
\text { accounted for. Ca, Ge, US similar. } \\
\text { Fr, It smaller (though possibly no } \\
\text { exchange rate channel). Ja, UK in } \\
\text { between. }\end{array}$ \\
\hline Ramaswamy \& Sloek (1997) & $\begin{array}{l}\mathrm{Au}, \mathrm{Be} \\
\mathrm{Dk}, \mathrm{Fi}, \mathrm{Fr} \\
\mathrm{Ge}, \mathrm{It}, \mathrm{Ne} \\
\mathrm{Po}, \mathrm{Sp} \\
\mathrm{Sw}, \mathrm{UK}\end{array}$ & VAR & $\begin{array}{l}\text { 3. Real GDP, CPI, } \\
\text { money market rate }\end{array}$ & $\begin{array}{l}\text { 1972:1 - 1995:4 } \\
\text { Quarterly }\end{array}$ & $\begin{array}{l}\text { VAR in levels. Cholesky decompositon with } \\
\text { causal order: GDP and CPI to money market } \\
\text { rate. Since only interested in effects of } \\
\text { monetary shocks, order of GDP and CPI is } \\
\text { unimportant. Equivalent to saying monetary } \\
\text { shocks have no contemporaneous effect on } \\
\text { GDP or CPI. }\end{array}$ & $\begin{array}{l}\text { Two groups. Effect in } \mathrm{Au}, \mathrm{Be}, \mathrm{Fi} \\
\mathrm{Ge}, \mathrm{Ne}, \mathrm{UK} \text {, takes twice as long to } \\
\text { occur and is roughly twice as } \\
\text { deep as the rest: De, Fr, It, Po, } \\
\mathrm{Sp}, \mathrm{Sw} \text {. }\end{array}$ \\
\hline Kieler \& Saarenheimo (1998) & $\begin{array}{l}\mathrm{Fr}, \mathrm{Ge}, \& \\
\text { UK }\end{array}$ & VAR & $\begin{array}{l}\text { 3. Real GDP, CPI, } \\
\text { money market rate }\end{array}$ & $\begin{array}{l}\text { Early 70's - } 1997 \\
\text { Q3. Quarterly }\end{array}$ & $\begin{array}{l}\text { VAR in levels. Cholesky decomposition with } \\
\text { order: Output- price level - interest rate. Took } \\
\text { this orthoganalisation and rotated it in three } \\
\text { diminsional space in order to generate many } \\
\text { more orthoganalisations for which impulse } \\
\text { responses were calculated. Then, any } \\
\text { responses that looked sensible were added to } \\
\text { the plausible set. }\end{array}$ & $\begin{array}{l}\text { Taking into account all "plausible" } \\
\text { identification schemes found little } \\
\text { difference between transmission } \\
\text { in the different countries. Also } \\
\text { noted that differentness of UK } \\
\text { comes from exchange rate } \\
\text { assumption (fixed/floating). }\end{array}$ \\
\hline
\end{tabular}




\begin{tabular}{|c|c|c|c|c|c|c|}
\hline Philipsen \& Wuyts (1999) & $\begin{array}{l}\mathrm{Be}, \mathrm{Dk}, \mathrm{Fi} \\
\mathrm{Fr}, \mathrm{Ge} \\
\mathrm{Gr}, \mathrm{Ir}, \mathrm{It} \\
\mathrm{Ne}, \mathrm{Po} \\
\mathrm{Sp}, \mathrm{Sw} \\
\mathrm{UK}\end{array}$ & VAR & $\begin{array}{l}\text { 3. IPI, CPI, money } \\
\text { market rate }\end{array}$ & \begin{tabular}{|l|} 
Jan 1972 - Dec \\
1998. Monthly
\end{tabular} & $\begin{array}{l}\text { VAR in levels. Cholesky decompositon with } \\
\text { causal order: GDP and CPI to money market } \\
\text { rate. Since only interested in effects of } \\
\text { monetary shocks, order of GDP and CPI is } \\
\text { unimportant. Equivalent to saying monetary } \\
\text { shocks have no contemporaneous effect on } \\
\text { GDP or CPI. }\end{array}$ & $\begin{array}{l}\text { Effects of policy noticeably bigger } \\
\text { in Be, Fi, Dk, It. Others are quite } \\
\text { similar. }\end{array}$ \\
\hline $\begin{array}{l}\text { Barran, Coudert \& Mojon } \\
\text { (1996) }\end{array}$ & $\begin{array}{l}\mathrm{Au}, \mathrm{Dk}, \mathrm{Fi}, \\
\mathrm{Fr}, \mathrm{Ge}, \mathrm{It}, \\
\mathrm{Ne}, \mathrm{Sp} \\
\mathrm{UK}\end{array}$ & VAR & $\begin{array}{l}\text { 5. GDP, CPI, } \\
\text { World Export } \\
\text { Price, Exchange } \\
\text { Rate, Call Money } \\
\text { Market Rate }\end{array}$ & $\begin{array}{l}\text { Country } \\
\text { dependent, } \\
\text { Mainly 1976:1 - } \\
\text { 1994. Quarterly }\end{array}$ & $\begin{array}{l}\text { Use various different VARs to analyse different } \\
\text { questions. All based on VAR identified with } \\
\text { Cholesky decomposition. Causal order: GDP, } \\
\text { CPI, World Export Price, Exchange Rate, Call } \\
\text { Money Market Rate. }\end{array}$ & $\begin{array}{l}\text { Mostly similar responses and lags } \\
\text { except in magnitudes. Ge esp } \\
\text { high, Scandinavian Countries } \\
\text { lowest. Other in between. Effects } \\
\text { last longest in Ge, and Au. }\end{array}$ \\
\hline Dedola \& Lippi (2004) & $\begin{array}{l}\text { Fr, Ge, It, } \\
\text { UK, US. }\end{array}$ & VAR & $\begin{array}{l}\text { 5/6. IPI, CPI, } \\
\text { commodity price } \\
\text { index, } 3 \text { month } \\
\text { interbank interest } \\
\text { rate (Fed funds } \\
\text { rate for US), M3 } \\
\text { (US M1). Non US } \\
\text { also have trade } \\
\text { weighted } \\
\text { exchange rate }\end{array}$ & \begin{tabular}{|l} 
Jan $1975-$ Mar \\
1997. Monthly
\end{tabular} & $\begin{array}{l}\text { Cholesky approach. Ordering of variables: } \\
\text { Industrial Production, CPI, Commodity Price } \\
\text { Index, stir, a monetary aggregate. }\end{array}$ & $\begin{array}{l}\text { Ge most affected, It next most, Fr, } \\
\text { UK \& US least affected. }\end{array}$ \\
\hline
\end{tabular}




\begin{tabular}{|c|c|c|c|c|c|c|}
\hline Ehrmann (2000) & $\begin{array}{l}\mathrm{Au}, \mathrm{Be}, \\
\mathrm{Dk}, \mathrm{Fi}, \mathrm{Fr}, \\
\mathrm{Ge}, \mathrm{Ir}, \mathrm{It} \\
\mathrm{Ne}, \mathrm{Po} \\
\mathrm{Sp}, \mathrm{Sw} \\
\mathrm{UK}\end{array}$ & \begin{tabular}{|c|} 
VECM \\
\\
\\
\end{tabular} & $\begin{array}{l}\text { 4/5. IPI, CPI, } 3 \\
\text { month money } \\
\text { market/ treasury } \\
\text { bill rate, DM or \$ } \\
\text { exchange rate, } \\
\text { plus extra interest } \\
\text { rate (Ge short } \\
\text { term or own long } \\
\text { term rate) or } \\
\text { commodity price } \\
\text { index }\end{array}$ & $\begin{array}{l}1984-1997 \\
\text { Except Ge 1979-, } \\
\text { Po 1983-, UK } \\
\text { 1980-. Quarterly }\end{array}$ & $\begin{array}{l}\text { SVAR with short term interest rates, inflation, } \\
\text { real industrial production, exchange rate, \& CB } \\
\text { behaviour. First four common to all countries. } \\
\text { Long term interest rates (Fr, Sw), Ge short term } \\
\text { interest rate. (Au,Be, Ne), Commodity prices } \\
(\mathrm{Ge}, \mathrm{UK}) \text {, or special (Sp). Identification: } \\
\text { Cointegration as suggested by Johansen } \\
\text { method plus no contemporaneus effect of } \\
\text { monetary policy. }\end{array}$ & $\begin{array}{l}\text { Large variation across countries, } \\
\text { esp UK which is impacted much } \\
\text { more by similar shock. }\end{array}$ \\
\hline Mojon \& Peersman (2002) & $\begin{array}{l}\mathrm{Au}, \mathrm{Be}, \mathrm{Fi} \\
\mathrm{Fr}, \mathrm{Ge}, \mathrm{Ir} \\
\mathrm{It}, \mathrm{Ne}, \mathrm{Po}, \\
\mathrm{Sp}\end{array}$ & VAR & $\begin{array}{l}\text { 4/5 endogenous. } \\
\text { GDP, CPI, STIR, } \\
\text { real effective } \\
\text { exchange rate. } \\
\text { Non-core } \\
\text { countries also Ge } \\
\text { STIR as } \\
\text { endogenous. }\end{array}$ & $\begin{array}{l}\text { 1980:1-1998:4. } \\
\text { Quarterly. Ge } \\
\text { 1970:1-1998:4. }\end{array}$ & $\begin{array}{l}\text { identification schemes: } 1 \text { for Ge, } 1 \text { for core } \\
\text { (Au, Be, Ne) and } 1 \text { for other countries. Use } \\
\text { exogenous variables to allow for Ge leadership. } \\
\text { Ge exogenous vars: commodity prices, US } \\
\text { GDP, US STIR. Core ex: as Ge plus block } \\
\text { exogenous Ge VAR model; use Ge shocks for } \\
\text { analysis. Non-core ex: as Ge; use bilateral DM } \\
\text { exchange rate instead of real effective } \\
\text { exchange rate. }\end{array}$ & $\begin{array}{l}\text { Given width of Cl cannot reject } \\
\text { broadly similar transmission } \\
\text { mechanism. Ne, Fi show largest } \\
\text { output effect; Po, It, Sp show } \\
\text { smallest. Others similar. }\end{array}$ \\
\hline Altavilla (2000) & $\begin{array}{l}\mathrm{Au}, \mathrm{Be}, \mathrm{Fi} \\
\mathrm{Fr}, \mathrm{Ge}, \mathrm{Ir} \\
\mathrm{It}, \mathrm{Ne}, \mathrm{Po}, \\
\mathrm{Sp}\end{array}$ & VECM & $\begin{array}{l}\text { 5. Real IPI, CPI, } \\
\text { nominal short term } \\
\text { interest rate, } \\
\text { commodity price } \\
\text { index, real } \\
\text { exchange rate }\end{array}$ & $\begin{array}{l}\text { 1979:1 to } 1998: 4 . \\
\text { Quarterly }\end{array}$ & $\begin{array}{l}\text { Altavilla uses both contemporaneus and } \\
\text { cointegration restrictions to identify the five } \\
\text { variable SVAR. The variables are nominal short } \\
\text { term interest rate, output, inflation, commodity } \\
\text { price index, and the real exchange rate. Only } \\
\text { the latter is assumed to be affected } \\
\text { contemporaneously by monetary shocks. }\end{array}$ & $\begin{array}{l}\text { There are asymmetries between } \\
\text { the countries but these are mainly } \\
\text { in the response of real output to } \\
\text { the monetary policy shock. Larger } \\
\text { response in Fr, Fi, Ge, It, Po than } \\
\text { in the rest. This group includes } \\
\text { three out of four larger counties. }\end{array}$ \\
\hline
\end{tabular}




\begin{tabular}{|l|l|l|l|l|l|}
\hline $\begin{array}{l}\text { Clements, Kontolemis \& Levy } \\
\text { (2001) }\end{array}$ & $\begin{array}{l}\text { Au, Be, Fi, } \\
\text { Fr, Ge, Ir, } \\
\text { It, Ne, Po, } \\
\text { Sp }\end{array}$ & $\begin{array}{l}\text { 5 GDP, CPI, STIR,, } \\
\text { effective exchange } \\
\text { rate, private sector } \\
\text { credit }\end{array}$ & $\begin{array}{l}1983: 1 \text { to 1998:4. } \\
\text { Quarterly. }\end{array}$ & $\begin{array}{l}\text { Cholesky decomposition with ordering as per } \\
\text { variables list. Dummies for Ge reunification and } \\
\text { for USSR break-up for Fi. }\end{array}$ & $\begin{array}{l}\text { Au, Ge, and Ne have largest } \\
\text { effects, Fi and Sp smallest. Others } \\
\text { in between. }\end{array}$ \\
\hline Kim \& Roubini (2000) & $\begin{array}{l}\text { Ca, Fr, } \\
\text { Ge, It, Ja, } \\
\text { UK }\end{array}$ & SVAR & $\begin{array}{l}\text { 7. Oil price, US } \\
\text { Fed Funds Rate, } \\
\text { IPI, CPI, money, } \\
\text { STIR, \$ exchange } \\
\text { rate }\end{array}$ & $\begin{array}{l}1974: 7 \text { to } \\
1992: 12 . \text { Monthly. } \\
\text { Fr -92:2, Ca 92:5. }\end{array}$ & $\begin{array}{l}\text { Structural VAR based upon information } \\
\text { restrictions. Monetary policy does not respond } \\
\text { contemporaneously to IPI, CPI or the Fed } \\
\text { Funds Rate. 1 standard deviation shocks. See } \\
\text { Kim and Roubini for further details. }\end{array}$ \\
\hline
\end{tabular}


Table 2. The models compared

\begin{tabular}{|l|l|l|l|}
\hline Model & Endognenous Variables & $\begin{array}{l}\text { Exogenous } \\
\text { Variables }\end{array}$ & Notes \\
\hline Q73 & GDP, CPI, STIR & & Cholesky Decomposition \\
\hline Q80 & GDP, CPI, STIR & & Cholesky Decomposition \\
\hline Q731D & D GDP, D CPI, STIR & & Cholesky Decomposition \\
\hline Q73ПG & D GDP, D CPI, STIR & & Cholesky Decomposition \\
\hline Q80ПG & HP GDP,, CPI Inflation (Year & & Cholesky Decomposition \\
\hline Q80GEIR & GDP, CPI, STIR & & Cholesky Decomposition \\
\hline Q73GEIR & GDP, CPI, STIR & German STIR & Cholesky Decomposition \\
\hline Q73OIL & GDP, CPI, STIR & German STIR & Cholesky Decomposition \\
\hline Q80OIL & GDP, CPI, STIR & World Oil Price & Cholesky Decomposition \\
\hline Q73IRD & GDP, CPI, STIRD & World Oil Price & Cholesky Decomposition \\
\hline Q80IRD & GDP, CPI, STIRD & & Cholesky Decomposition \\
\hline Q73IRDV & GDP, CPI, STIRD & & Cholesky Decomposition \\
\hline Q80IRDV & GDP, CPI, STIRD & & VECM using Johansen's method \\
\hline Q73BQ & GDP, CPI, STIR & & VECM using Johansen's method \\
\hline Q80BQ & GDP, CPI, STIR & & $\begin{array}{l}\text { STIR shocks have no long-run effects } \\
\text { on GDP or CPI }\end{array}$ \\
\hline Q73M & GDP, CPI, STIR, Money & & $\begin{array}{l}\text { STIR shocks have no long-run effects } \\
\text { on GDP or CPI }\end{array}$ \\
\hline Q80M & GDP, CPI, STIR, Money & & Cholesky Decomposition \\
\hline Q73E & GDP, CPI, STIR, NEER & & Cholesky Decomposition \\
\hline Q73IPI & GDP, CPI, STIR, NEER & & Cholesky Decomposition \\
\hline Q80IPI & IPI, CPI, STIR & & Cholesky Decomposition \\
\hline
\end{tabular}


Table 2 (cont): The models compared.

\begin{tabular}{|c|c|c|c|}
\hline Model & Endognenous Variables & $\begin{array}{l}\text { Exogenous } \\
\text { Variables } \\
\end{array}$ & Notes \\
\hline M73 & IPI, CPI, STIR & & Cholesky Decomposition \\
\hline M80 & IPI, CPI, STIR & & Cholesky Decomposition \\
\hline M731D & D IPI, D CPI, STIR & & Cholesky Decomposition \\
\hline M801D & D IPI, D CPI, STIR & & Cholesky Decomposition \\
\hline M73ПG & $\begin{array}{l}\text { HP IPI, CPI Inflation (Year } \\
\text { on Year), STIR }\end{array}$ & & Cholesky Decomposition \\
\hline M80ПG & $\begin{array}{l}\text { HP IPI, CPI Inflation (Year } \\
\text { on Year), STIR }\end{array}$ & & Cholesky Decomposition \\
\hline M73GEIR & IPI, CPI, STIR & German STIR & Cholesky Decomposition \\
\hline M80GEIR & IPI, CPI, STIR & German STIR & Cholesky Decomposition \\
\hline M73OIL & IPI, CPI, STIR & World Oil Price & Cholesky Decomposition \\
\hline M80OIL & IPI, CPI, STIR & World Oil Price & Cholesky Decomposition \\
\hline M73IRD & IPI, CPI, STIRD & & Cholesky Decomposition \\
\hline M80IRD & IPI, CPI, STIRD & & Cholesky Decomposition \\
\hline M73IRDV & IPI, CPI, STIRD & & VECM using Johansen's method \\
\hline M80IRDV & IPI, CPI, STIRD & & VECM using Johansen's method \\
\hline M73BQ & IPI, CPI, STIR & & $\begin{array}{l}\text { STIR shocks have no long-run effects } \\
\text { on GDP or CPI }\end{array}$ \\
\hline M80BQ & IPI, CPI, STIR & & $\begin{array}{l}\text { STIR shocks have no long-run effects } \\
\text { on GDP or CPI }\end{array}$ \\
\hline M73M & IPI, CPI, STIR, Money & & Cholesky Decomposition \\
\hline M80M & IPI, CPI, STIR, Money & & Cholesky Decomposition \\
\hline M73E & IPI, CPI, STIR, NEER & & Cholesky Decomposition \\
\hline M80E & IPI, CPI, STIR, NEER & & Cholesky Decomposition \\
\hline KRM80 & $\begin{array}{l}\text { IPI, CPI, STIR, World Oil } \\
\text { Price, German (or US) STIR, } \\
\text { Nominal Exchange Rate with } \\
\text { DM (or US\$), Money }\end{array}$ & & SVAR based on Kim and Roubini \\
\hline
\end{tabular}

The models are named so that the first letter indicates quarterly (Q) or monthly (M) data, then the number indicates the sample period: 1973-98 (73) or 1980-98 (80). GDP is Gross Domestic Product, IPI is an Industrial Production Index, CPI is a Consumer Price Index, STIR is a Short-Term Interest Rate, STIRD is the Short-Term Interest Rate Differential vis-à-vis Germany (the US for Germany), HP indicates the use of the Hodrick-Prescott filter, D represents the first difference operator, NEER is the Nominal Effective Exchange Rate. Models with GDP for Germany also included a reunification dummy. 


\section{Table 3: Data sources}

All data from the International Financial Statistics, IMF except for the nominal exchange rate vs. Germany used in the KRM80 model, which is from the Bundesbank. Salient features of the data series described below.

\begin{tabular}{|l|c|c|}
\hline & Interest rate & Money \\
\hline Austria & Money Market Rate & M1 \\
\hline Belgium & Call Money Rate & M3 (Starts 1979M12) \\
\hline Finland & Central Bank Rate & M3 (Starts 1974M12) \\
\hline France & Call Money Rate & M1 (Starts 1977M12) \\
\hline Germany & Call Money Rate & M1 \\
\hline Italy & Money Market Rate & M2 (Starts 1974M12) \\
\hline Netherlands & Call Money Rate & M2 (Ends 1997M12) \\
\hline Spain & Bank Of Spain Rate & M1 \\
\hline Sweden & Call Money Rate & National definition \\
\hline UK & Interbank rate & M0 \\
\hline
\end{tabular}


Table 4. Average Pearson correlation between price responses from one VAR model with the rest

\begin{tabular}{|c|c|c|c|c|c|c|}
\hline & Peak & Timing & Sum (60) & $\begin{array}{l}\text { Sum }(60)>0 \\
\quad=\text { Zero }\end{array}$ & $\begin{array}{l}\text { Sum }(60)>0 \\
=\text { Blank }\end{array}$ & Sum (36) \\
\hline Q73 & 0.17 & 0.11 & 0.16 & - & - & 0.15 \\
\hline Q80 & 0.32 & 0.31 & 0.05 & 0.04 & 0.24 & 0.04 \\
\hline Q731D & 0.24 & 0.13 & 0.19 & 0.09 & -0.03 & 0.20 \\
\hline Q801D & 0.21 & 0.20 & 0.07 & 0.12 & - & 0.09 \\
\hline Q73ПG & -0.22 & 0.08 & 0.13 & -0.03 & -0.24 & 0.11 \\
\hline Q80ПG & 0.15 & 0.27 & 0.12 & -0.02 & - & 0.14 \\
\hline Q73GEIR & 0.36 & 0.26 & 0.16 & 0.09 & 0.40 & 0.20 \\
\hline Q80GEIR & 0.24 & 0.34 & 0.03 & 0.15 & 0.24 & 0.04 \\
\hline Q73OIL & 0.20 & 0.24 & 0.08 & 0.09 & - & 0.08 \\
\hline Q80OIL & 0.22 & 0.31 & 0.05 & 0.09 & 0.40 & 0.01 \\
\hline Q73IRD & 0.34 & 0.24 & 0.12 & 0.18 & -0.12 & 0.08 \\
\hline Q80IRD & 0.21 & 0.28 & -0.03 & 0.13 & 0.18 & -0.01 \\
\hline Q73IRDV & 0.38 & 0.17 & 0.07 & 0.19 & 0.31 & 0.03 \\
\hline Q80IRDV & 0.21 & 0.36 & -0.05 & 0.12 & 0.12 & -0.01 \\
\hline Q73BQ & 0.26 & - & -0.10 & 0.12 & 0.06 & -0.09 \\
\hline Q80BQ & 0.21 & - & -0.06 & 0.12 & 0.15 & -0.02 \\
\hline Q73M & 0.25 & 0.20 & 0.16 & 0.15 & - & 0.16 \\
\hline Q80M & 0.30 & 0.35 & 0.05 & 0.12 & 0.58 & 0.03 \\
\hline Q73E & -0.05 & -0.18 & 0.10 & - & - & 0.08 \\
\hline Q80E & 0.33 & 0.37 & 0.04 & -0.06 & - & 0.02 \\
\hline Q73IPI & 0.01 & 0.06 & 0.16 & 0.14 & - & 0.18 \\
\hline Q80IPI & 0.15 & 0.24 & 0.08 & 0.10 & 0.29 & 0.10 \\
\hline
\end{tabular}


Table 4 (cont): Average Pearson correlation between price responses from one VAR model with the rest and the overall mean correlation across all VARs.

\begin{tabular}{|c|c|c|c|c|c|c|}
\hline & Peak & Timing & Sum (60) & $\begin{array}{l}\text { Sum }(60)>0 \\
=\text { Zero }\end{array}$ & $\begin{array}{l}\text { Sum }(60)>0 \\
=\text { Blank }\end{array}$ & Sum (36) \\
\hline M73 & 0.07 & -0.31 & 0.00 & - & - & 0.10 \\
\hline M80 & 0.07 & 0.27 & 0.14 & - & - & 0.18 \\
\hline M731D & 0.00 & 0.22 & 0.08 & -0.10 & - & 0.15 \\
\hline M801D & 0.14 & -0.20 & 0.05 & - & - & 0.15 \\
\hline М73ПG & 0.04 & 0.31 & 0.14 & -0.02 & 0.07 & 0.17 \\
\hline М80ПG & 0.21 & 0.20 & 0.09 & 0.14 & - & 0.10 \\
\hline M73GEIR & 0.12 & -0.20 & 0.07 & -0.03 & - & 0.17 \\
\hline M80GEIR & 0.36 & 0.33 & 0.11 & 0.09 & 0.15 & 0.17 \\
\hline M73OIL & 0.13 & -0.01 & 0.07 & 0.08 & - & 0.15 \\
\hline M80OIL & 0.06 & 0.27 & 0.14 & 0.14 & - & 0.19 \\
\hline M73IRD & 0.24 & -0.02 & -0.08 & 0.06 & -0.23 & -0.06 \\
\hline M80IRD & 0.40 & 0.36 & 0.00 & 0.23 & 0.47 & 0.01 \\
\hline M73IRDV & 0.11 & 0.16 & 0.02 & 0.05 & -0.10 & 0.01 \\
\hline M80IRDV & 0.36 & 0.32 & 0.02 & 0.23 & 0.41 & 0.00 \\
\hline M73BQ & 0.20 & - & -0.05 & 0.14 & 0.16 & -0.15 \\
\hline M80BQ & 0.09 & 0.21 & -0.17 & 0.00 & 0.31 & -0.22 \\
\hline M73M & -0.04 & 0.11 & 0.04 & - & - & 0.12 \\
\hline M80M & -0.05 & 0.26 & 0.08 & - & - & 0.16 \\
\hline M73E & 0.08 & -0.38 & -0.01 & - & - & 0.09 \\
\hline M80E & 0.31 & 0.33 & 0.06 & - & - & 0.08 \\
\hline KRM80 & 0.01 & 0.19 & -0.26 & -0.09 & 0.12 & -0.26 \\
\hline Mean & 0.17 & 0.16 & 0.05 & 0.08 & 0.17 & 0.07 \\
\hline
\end{tabular}


Table 5. Average Pearson correlation between output responses from one VAR model with the rest

\begin{tabular}{|l|cccccc|}
\hline & Peak & Timing & Sum (60) & $\begin{array}{c}\text { Sum }(60)>0 \\
=\text { Zero }\end{array}$ & $\begin{array}{c}\text { Sum }(60)>0 \\
=\text { Blank }\end{array}$ & Sum (36) \\
\hline Q73 & & & & & & \\
Q80 & 0.72 & 0.20 & 0.56 & 0.69 & 0.77 & 0.59 \\
Q731D & 0.69 & 0.20 & 0.56 & 0.69 & 0.83 & 0.60 \\
Q801D & 0.74 & -0.20 & 0.57 & 0.70 & 0.79 & 0.59 \\
Q73ПG & 0.73 & 0.05 & 0.53 & 0.65 & 0.78 & 0.57 \\
Q80ПG & 0.66 & -0.03 & 0.54 & 0.65 & 0.73 & 0.54 \\
Q73GEIR & 0.71 & -0.12 & 0.56 & 0.69 & 0.82 & 0.59 \\
Q80GEIR & 0.74 & 0.22 & 0.55 & 0.69 & 0.80 & 0.57 \\
Q73OIL & 0.74 & 0.26 & 0.56 & 0.69 & 0.82 & 0.59 \\
Q80OIL & 0.73 & 0.20 & 0.56 & 0.70 & 0.82 & 0.59 \\
Q73IRD & 0.68 & 0.19 & 0.55 & 0.68 & 0.82 & 0.60 \\
Q80IRD & 0.72 & 0.06 & -0.14 & -0.08 & 0.32 & 0.19 \\
Q73IRDV & 0.67 & -0.05 & 0.22 & 0.30 & 0.43 & 0.36 \\
Q80IRDV & 0.62 & 0.06 & -0.26 & -0.06 & 0.13 & 0.05 \\
Q73BQ & 0.67 & 0.10 & 0.50 & 0.65 & 0.77 & 0.56 \\
Q80BQ & 0.62 & 0.22 & -0.59 & - & - & -0.63 \\
Q73M & 0.42 & 0.19 & -0.46 & -0.14 & - & -0.54 \\
Q80M & 0.71 & 0.13 & 0.56 & 0.69 & 0.76 & 0.60 \\
Q73E & 0.68 & 0.17 & 0.54 & 0.67 & 0.80 & 0.59 \\
Q80E & 0.71 & 0.15 & 0.55 & 0.68 & 0.74 & 0.58 \\
Q73IPI & 0.67 & 0.16 & 0.53 & 0.67 & 0.81 & 0.57 \\
Q80IPI & 0.46 & 0.14 & 0.33 & 0.44 & 0.58 & 0.38 \\
\hline
\end{tabular}


Table 5 (cont): Average Pearson correlation between output responses from one VAR model with the rest and the overall mean correlation across all VARs.

\begin{tabular}{|c|c|c|c|c|c|c|}
\hline & Peak & Timing & Sum (60) & $\begin{array}{l}\text { Sum }(60)>0 \\
=\text { Zero }\end{array}$ & $\begin{array}{l}\text { Sum }(60)>0 \\
=\text { Blank }\end{array}$ & Sum (36) \\
\hline M73 & 0.74 & 0.03 & 0.52 & 0.66 & 0.72 & 0.56 \\
\hline M80 & 0.73 & 0.06 & 0.55 & 0.67 & 0.80 & 0.58 \\
\hline M731D & 0.41 & 0.01 & 0.49 & 0.63 & 0.75 & 0.48 \\
\hline M801D & 0.50 & -0.07 & 0.50 & 0.63 & 0.75 & 0.52 \\
\hline М73ПG & 0.41 & 0.14 & 0.51 & 0.68 & 0.87 & 0.49 \\
\hline М80ПG & 0.39 & 0.10 & 0.55 & 0.68 & 0.80 & 0.56 \\
\hline M73GEIR & 0.73 & 0.08 & 0.51 & 0.65 & 0.70 & 0.53 \\
\hline M80GEIR & 0.75 & 0.12 & 0.55 & 0.68 & 0.80 & 0.58 \\
\hline M73OIL & 0.73 & 0.10 & 0.53 & 0.67 & 0.79 & 0.56 \\
\hline M80OIL & 0.74 & 0.07 & 0.55 & 0.67 & 0.85 & 0.58 \\
\hline M73IRD & 0.56 & -0.08 & 0.26 & 0.35 & 0.43 & 0.34 \\
\hline M80IRD & 0.15 & -0.04 & -0.08 & -0.12 & 0.38 & 0.02 \\
\hline M73IRDV & 0.45 & -0.05 & 0.03 & 0.02 & -0.11 & 0.19 \\
\hline M80IRDV & -0.02 & -0.02 & -0.32 & -0.23 & 0.22 & -0.27 \\
\hline M73BQ & 0.57 & 0.21 & -0.49 & - & - & -0.52 \\
\hline M80BQ & 0.01 & 0.00 & -0.48 & -0.06 & - & -0.50 \\
\hline $\mathrm{M} 73 \mathrm{M}$ & 0.74 & -0.11 & 0.54 & 0.68 & 0.73 & 0.58 \\
\hline M80M & 0.73 & -0.19 & 0.55 & 0.68 & 0.74 & 0.59 \\
\hline M73E & 0.69 & 0.02 & 0.43 & 0.56 & 0.63 & 0.46 \\
\hline M80E & 0.71 & 0.06 & 0.41 & 0.59 & 0.80 & 0.51 \\
\hline KRM80 & 0.30 & 0.01 & 0.22 & 0.30 & 0.44 & 0.05 \\
\hline Mean & 0.59 & 0.07 & 0.32 & 0.49 & 0.66 & 0.36 \\
\hline
\end{tabular}


Table 6. Average Pearson correlation among recursive VARs

\begin{tabular}{|l|cc|cc|}
\hline & \multicolumn{2}{|c|}{ Prices } & \multicolumn{2}{c|}{ Output } \\
& Peak & Sum $(60)$ & Peak & Sum (60) \\
\hline Q73 & 0.23 & 0.33 & 0.88 & 0.88 \\
Q80 & 0.21 & 0.22 & 0.86 & 0.87 \\
Q73GEIR & 0.28 & 0.15 & 0.88 & 0.89 \\
Q80GEIR & 0.12 & -0.16 & 0.89 & 0.89 \\
Q73OIL & 0.18 & 0.22 & 0.89 & 0.89 \\
Q80OIL & 0.15 & 0.22 & 0.85 & 0.86 \\
Q73M & 0.19 & 0.24 & 0.87 & 0.87 \\
Q80M & 0.22 & 0.20 & 0.84 & 0.83 \\
Q73E & 0.04 & 0.31 & 0.86 & 0.86 \\
Q80E & 0.22 & 0.23 & 0.84 & 0.84 \\
Q73IPI & 0.03 & 0.37 & 0.53 & 0.51 \\
Q80IPI & 0.03 & 0.27 & 0.19 & 0.19 \\
M73 & 0.16 & 0.06 & 0.86 & 0.86 \\
M80 & 0.11 & 0.18 & 0.88 & 0.87 \\
M73GEIR & 0.21 & 0.11 & 0.84 & 0.85 \\
M80GEIR & 0.39 & 0.07 & 0.88 & 0.89 \\
M73OIL & 0.20 & 0.16 & 0.86 & 0.87 \\
M80OIL & 0.11 & 0.20 & 0.88 & 0.88 \\
M73M & -0.06 & 0.11 & 0.87 & 0.87 \\
M80M & -0.04 & 0.19 & 0.89 & 0.88 \\
M73E & 0.17 & 0.04 & 0.76 & 0.73 \\
M80E & 0.37 & -0.01 & 0.81 & 0.66 \\
\hline Mean & 0.16 & 0.17 & 0.81 & 0.81 \\
\hline
\end{tabular}


Table 7. Average Pearson correlation among VARs that suffer less from the price puzzle

\begin{tabular}{|l|cc|cc|}
\hline & \multicolumn{2}{|c|}{ Prices } & \multicolumn{2}{c|}{ Output } \\
& Peak & Sum (60) & Peak & Sum (60) \\
\hline Q80 & 0.55 & -0.26 & 0.58 & 0.50 \\
Q731D & 0.48 & 0.09 & 0.58 & 0.48 \\
Q80GEIR & 0.51 & 0.25 & 0.58 & 0.46 \\
Q80OIL & 0.27 & -0.25 & 0.58 & 0.49 \\
Q80IRD & 0.47 & 0.18 & 0.53 & 0.21 \\
Q80IRDV & 0.46 & 0.15 & 0.52 & 0.43 \\
M73ПG & -0.07 & -0.10 & 0.23 & 0.38 \\
M80IRD & 0.54 & 0.20 & 0.16 & 0.02 \\
M73IRDV & -0.03 & 0.03 & 0.27 & 0.06 \\
M80IRDV & 0.45 & 0.21 & 0.03 & -0.26 \\
KRM80 & 0.04 & -0.21 & 0.33 & 0.17 \\
\hline Mean & 0.33 & 0.03 & 0.40 & 0.27 \\
\hline
\end{tabular}

Note: Included are those specifications that gave a negative estimated price response when summed over 60 months. 
Table 8. Kendall rank correlation between estimated policy effects of the recursive VAR $3 Q 80$ and financial indicator statistics

\begin{tabular}{|c|c|c|c|c|c|c|c|c|}
\hline & \multicolumn{4}{|c|}{ Prices } & \multicolumn{4}{|c|}{ Output } \\
\hline & Peak & Time & $\begin{array}{c}\text { Sum } \\
(60)\end{array}$ & $\begin{array}{l}\text { Sum } \\
(36)\end{array}$ & Peak & Time & $\operatorname{Sum}(60)$ & Sum (36) \\
\hline \multicolumn{9}{|l|}{ Banking Industry } \\
\hline $\begin{array}{l}\text { Number of } \\
\text { Credit } \\
\text { Institutions }\end{array}$ & 0.07 & 0.30 & -0.29 & -0.33 & 0.24 & -0.33 & 0.24 & 0.29 \\
\hline $\begin{array}{l}\text { Banks Per } \\
\text { Million People }\end{array}$ & 0.02 & -0.09 & -0.34 & 0.02 & -0.02 & -0.39 & -0.02 & -0.07 \\
\hline $\begin{array}{l}\text { Concentration } \\
\text { Ratio: Top Five } \\
\text { Assets }\end{array}$ & -0.07 & $-0.55^{*}$ & 0.29 & $0.51 *$ & -0.33 & 0.28 & -0.33 & -0.29 \\
\hline \multicolumn{9}{|l|}{ Bank Health } \\
\hline $\begin{array}{l}\text { Return on } \\
\text { Assets }\end{array}$ & 0.00 & -0.22 & 0.18 & 0.23 & -0.14 & 0.36 & -0.14 & -0.18 \\
\hline $\begin{array}{l}\text { Loan Loss } \\
\text { Provisions }\end{array}$ & 0.09 & -0.12 & 0.14 & 0.27 & -0.05 & -0.22 & -0.05 & 0.00 \\
\hline $\begin{array}{l}\text { Net Interest } \\
\text { Margins }\end{array}$ & 0.11 & 0.12 & 0.29 & 0.16 & 0.02 & 0.00 & 0.02 & 0.07 \\
\hline Operating Costs & -0.11 & 0.18 & 0.07 & 0.20 & 0.16 & -0.05 & 0.16 & 0.11 \\
\hline $\begin{array}{l}\text { Average } \\
\text { Thomson } \\
\text { Rating }\end{array}$ & -0.02 & -0.30 & 0.07 & $0.47^{*}$ & -0.29 & -0.14 & -0.29 & -0.33 \\
\hline \multicolumn{9}{|c|}{ Importance of External Finance } \\
\hline $\begin{array}{l}\text { No Publicly } \\
\text { Traded Firms }\end{array}$ & 0.14 & 0.22 & 0.00 & -0.41 & 0.23 & 0.12 & 0.23 & 0.27 \\
\hline $\begin{array}{l}\text { Publicly Traded } \\
\text { Firms per } \\
\text { Capita }\end{array}$ & -0.20 & -0.37 & 0.16 & 0.38 & -0.29 & $0.47^{*}$ & -0.29 & -0.24 \\
\hline $\begin{array}{l}\text { Market Cap as } \\
\% \text { GDP }\end{array}$ & -0.24 & -0.12 & 0.02 & 0.24 & $-0.42 *$ & $0.66^{* *}$ & $-0.42 *$ & -0.38 \\
\hline $\begin{array}{l}\text { Corporate Debt } \\
\text { as } \% \text { GDP }\end{array}$ & 0.02 & -0.30 & 0.02 & 0.07 & -0.24 & -0.05 & -0.24 & -0.29 \\
\hline $\begin{array}{l}\text { Bank Loans \% } \\
\text { of all Finance }\end{array}$ & 0.09 & -0.06 & 0.18 & -0.18 & $0.45^{*}$ & -0.26 & $0.45^{*}$ & 0.41 \\
\hline
\end{tabular}


Table 8 (cont): Kendall rank correlation between estimated policy effects of the recursive VAR 3Q80 and financial indicator statistics

\begin{tabular}{|c|c|c|c|c|c|c|c|c|}
\hline & \multicolumn{4}{|c|}{ Prices } & \multicolumn{4}{|c|}{ Output } \\
\hline & Peak & Time & $\begin{array}{l}\text { Sum } \\
(60)\end{array}$ & $\begin{array}{l}\text { Sum } \\
(36)\end{array}$ & Peak & Time & $\begin{array}{l}\text { Sum } \\
(60)\end{array}$ & $\begin{array}{l}\text { Sum } \\
(36)\end{array}$ \\
\hline \multicolumn{9}{|c|}{ Shareholder and Creditor Rights } \\
\hline $\begin{array}{l}\text { Shareholder } \\
\text { Rights }\end{array}$ & 0.08 & -0.23 & 0.19 & 0.08 & 0.03 & 0.26 & 0.03 & 0.14 \\
\hline $\begin{array}{l}\text { Creditor } \\
\text { Rights }\end{array}$ & 0.00 & -0.14 & 0.10 & 0.05 & $0.46^{*}$ & -0.19 & $0.46^{*}$ & 0.36 \\
\hline Enforcement & -0.28 & $-0.52 *$ & -0.08 & $0.48 *$ & $-0.53 *$ & 0.13 & $-0.53 *$ & $-0.53 *$ \\
\hline \multicolumn{9}{|c|}{ Cecchetti's Summary Statistics } \\
\hline Small Banks & 0.35 & 0.07 & -0.03 & -0.35 & $0.56^{*}$ & $-0.68 * *$ & $0.56^{*}$ & $0.51 *$ \\
\hline Bank Health & 0.19 & -0.08 & -0.08 & 0.08 & -0.36 & -0.24 & -0.36 & -0.36 \\
\hline $\begin{array}{l}\text { Alternative } \\
\text { Finance }\end{array}$ & 0.08 & -0.04 & 0.08 & -0.03 & 0.30 & -0.45 & 0.30 & 0.30 \\
\hline $\begin{array}{l}\text { Predicted } \\
\text { Effectiveness }\end{array}$ & 0.21 & 0.00 & -0.02 & -0.16 & 0.26 & $-0.64 * *$ & 0.26 & 0.21 \\
\hline
\end{tabular}


Table 9. Kendall rank correlation between estimated policy effects of the structural VAR KRM80 and financial indicator statistics

\begin{tabular}{|c|c|c|c|c|c|c|c|c|}
\hline & \multicolumn{4}{|c|}{ Prices } & \multicolumn{4}{|c|}{ Output } \\
\hline & Peak & Time & $\begin{array}{l}\text { Sum } \\
(60)\end{array}$ & $\begin{array}{l}\text { Sum } \\
(36)\end{array}$ & Peak & Time & Sum (60) & Sum (36) \\
\hline \multicolumn{9}{|c|}{ Banking Industry } \\
\hline $\begin{array}{l}\text { Number of } \\
\text { Credit } \\
\text { Institutions }\end{array}$ & -0.02 & -0.07 & -0.07 & 0.07 & 0.11 & 0.44 & -0.07 & 0.02 \\
\hline $\begin{array}{l}\text { Banks Per } \\
\text { Million People }\end{array}$ & -0.39 & 0.02 & -0.21 & -0.11 & -0.25 & 0.15 & -0.30 & -0.21 \\
\hline $\begin{array}{l}\text { Concentration } \\
\text { Ratio: Top } \\
\text { Five Assets }\end{array}$ & -0.24 & 0.16 & -0.20 & -0.07 & -0.29 & -0.34 & -0.20 & -0.38 \\
\hline \multicolumn{9}{|l|}{ Bank Health } \\
\hline $\begin{array}{l}\text { Return on } \\
\text { Assets }\end{array}$ & 0.05 & -0.05 & 0.00 & -0.14 & -0.09 & -0.42 & 0.00 & -0.09 \\
\hline $\begin{array}{l}\text { Loan Loss } \\
\text { Provisions }\end{array}$ & 0.05 & 0.00 & -0.27 & -0.14 & -0.18 & 0.37 & -0.45 & -0.18 \\
\hline $\begin{array}{l}\text { Net Interest } \\
\text { Margins }\end{array}$ & 0.38 & -0.02 & 0.07 & 0.02 & 0.07 & 0.29 & -0.02 & 0.24 \\
\hline $\begin{array}{l}\text { Operating } \\
\text { Costs }\end{array}$ & 0.16 & 0.02 & -0.16 & -0.11 & -0.16 & 0.39 & -0.33 & -0.07 \\
\hline $\begin{array}{l}\text { Average } \\
\text { Thomson } \\
\text { Rating }\end{array}$ & -0.20 & 0.38 & -0.16 & -0.20 & -0.24 & 0.34 & -0.24 & 0.02 \\
\hline \multicolumn{9}{|c|}{ Importance of External Finance } \\
\hline $\begin{array}{l}\text { No Publicly } \\
\text { Traded Firms }\end{array}$ & 0.14 & 0.27 & 0.18 & -0.05 & 0.36 & 0.02 & 0.36 & 0.36 \\
\hline $\begin{array}{l}\text { Publicly } \\
\text { Traded Firms } \\
\text { per Capita }\end{array}$ & -0.11 & 0.11 & 0.02 & -0.11 & -0.16 & -0.10 & 0.02 & -0.07 \\
\hline $\begin{array}{l}\text { Market Cap as } \\
\% \text { GDP }\end{array}$ & 0.02 & 0.24 & 0.07 & -0.16 & -0.11 & -0.15 & 0.07 & -0.02 \\
\hline $\begin{array}{l}\text { Corporate Debt } \\
\text { as } \% \text { GDP }\end{array}$ & -0.42 & 0.16 & -0.11 & -0.07 & -0.11 & $-0.53 *$ & 0.07 & -0.11 \\
\hline $\begin{array}{l}\text { Bank Loans \% } \\
\text { of all Finance }\end{array}$ & -0.09 & $-0.49 *$ & -0.18 & 0.05 & -0.05 & -0.07 & -0.18 & -0.23 \\
\hline
\end{tabular}


Table 9 (cont): Kendall rank correlation between estimated policy effects of the structural VAR KRM80 and financial indicator statistics

\begin{tabular}{|c|c|c|c|c|c|c|c|c|}
\hline & & & & & & & atput & \\
\hline & Peak & Time & $\begin{array}{l}\text { Sum } \\
(60)\end{array}$ & $\begin{array}{l}\text { Sum } \\
(36)\end{array}$ & Peak & Time & Sum (60) & $\begin{array}{l}\text { Sum } \\
(36)\end{array}$ \\
\hline Shareholder a & reditor & & & & & & & \\
\hline $\begin{array}{l}\text { Shareholder } \\
\text { Rights }\end{array}$ & 0.19 & 0.03 & 0.08 & -0.03 & 0.03 & 0.27 & -0.03 & 0.03 \\
\hline $\begin{array}{l}\text { Creditor } \\
\text { Rights }\end{array}$ & -0.15 & -0.41 & -0.10 & -0.21 & -0.05 & -0.08 & 0.00 & 0.00 \\
\hline Enforcement & -0.48 & -0.03 & -0.23 & -0.13 & -0.48 & -0.27 & -0.33 & -0.43 \\
\hline Cecchetti's Su & ary Stat & & & & & & & \\
\hline Small Banks & -0.08 & -0.24 & -0.19 & 0.03 & 0.13 & 0.06 & -0.13 & -0.08 \\
\hline Bank Health & -0.14 & 0.53 & -0.14 & -0.08 & -0.08 & 0.12 & -0.14 & 0.03 \\
\hline $\begin{array}{l}\text { Alternative } \\
\text { Finance }\end{array}$ & -0.08 & -0.08 & -0.24 & -0.03 & -0.08 & 0.41 & -0.35 & -0.13 \\
\hline $\begin{array}{l}\text { Predicted } \\
\text { Effectiveness }\end{array}$ & -0.16 & -0.02 & -0.16 & -0.02 & 0.02 & 0.25 & -0.16 & -0.07 \\
\hline
\end{tabular}


Table 10. Kendall rank correlations between the VAR estimates and the predicted policy effectiveness, after countries have been grouped into legal families

\begin{tabular}{|l|cc|}
\hline & 3Q80 & KRM80 \\
\hline Peak Inflation & 0.33 & -0.67 \\
Time Inflation & -0.33 & 0.00 \\
Sum Inflation 60 & 0.33 & -0.67 \\
Peak Onflation 36 & 0.00 & -0.67 \\
Timing Output & 0.33 & -0.33 \\
Sum Output 60 & -0.67 & $-1.00^{*}$ \\
Sum Output 36 & 0.33 & -0.67 \\
\hline
\end{tabular}


Figure 1. Correlations of the peak inflation effect

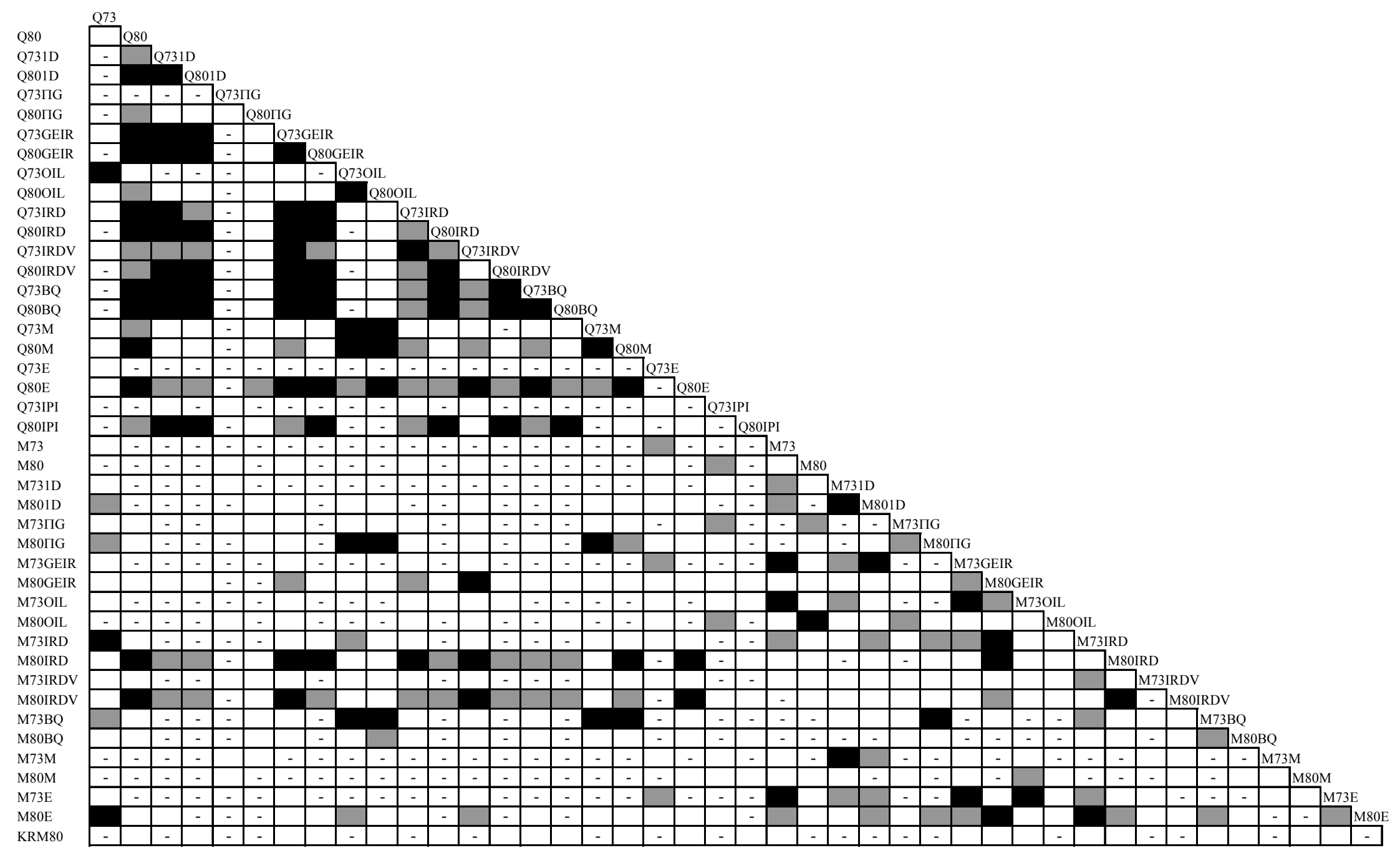


Figure 2. Correlations of the timing of the peak inflation effect

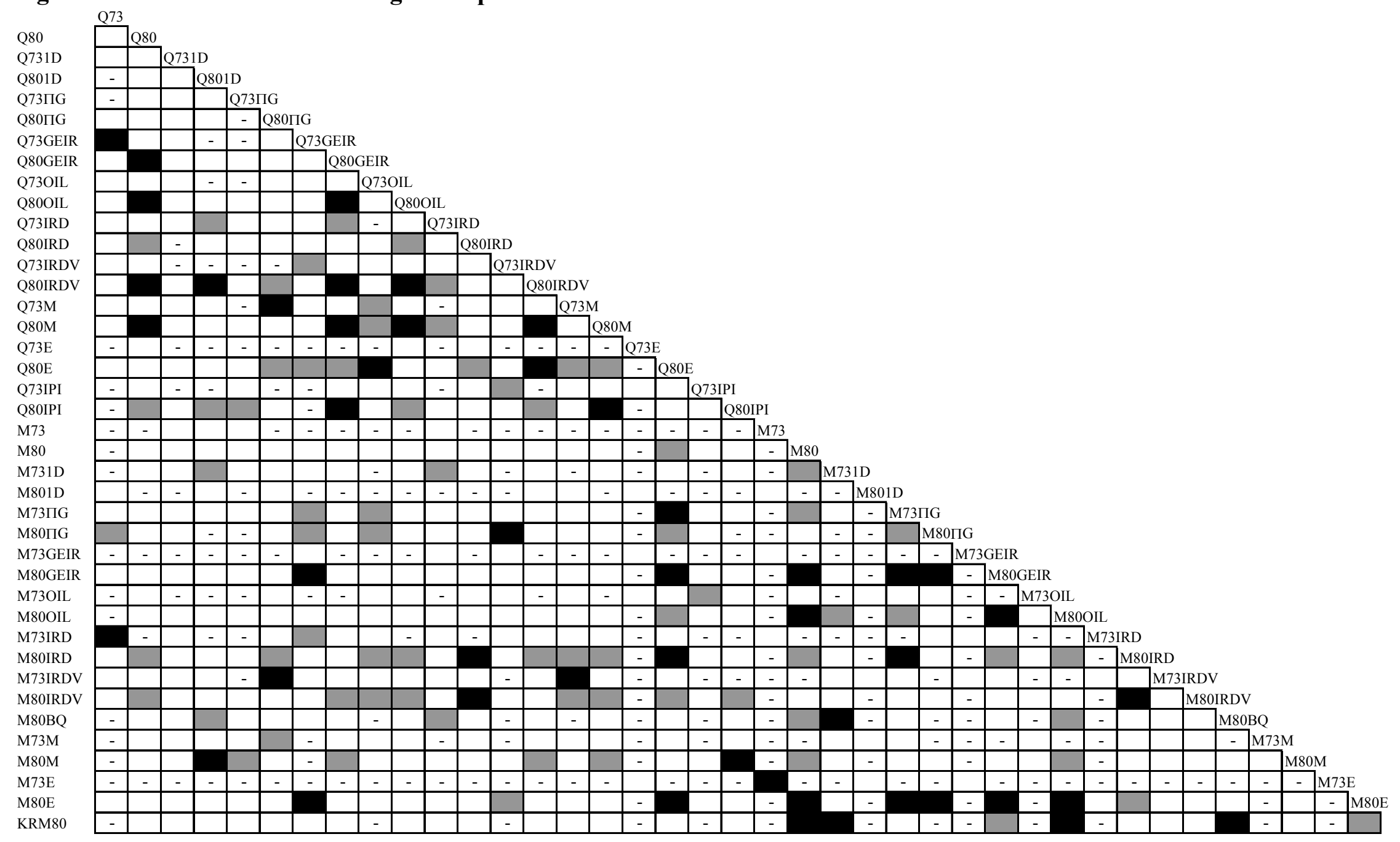


Figure 3. Correlations of the summed inflation effect

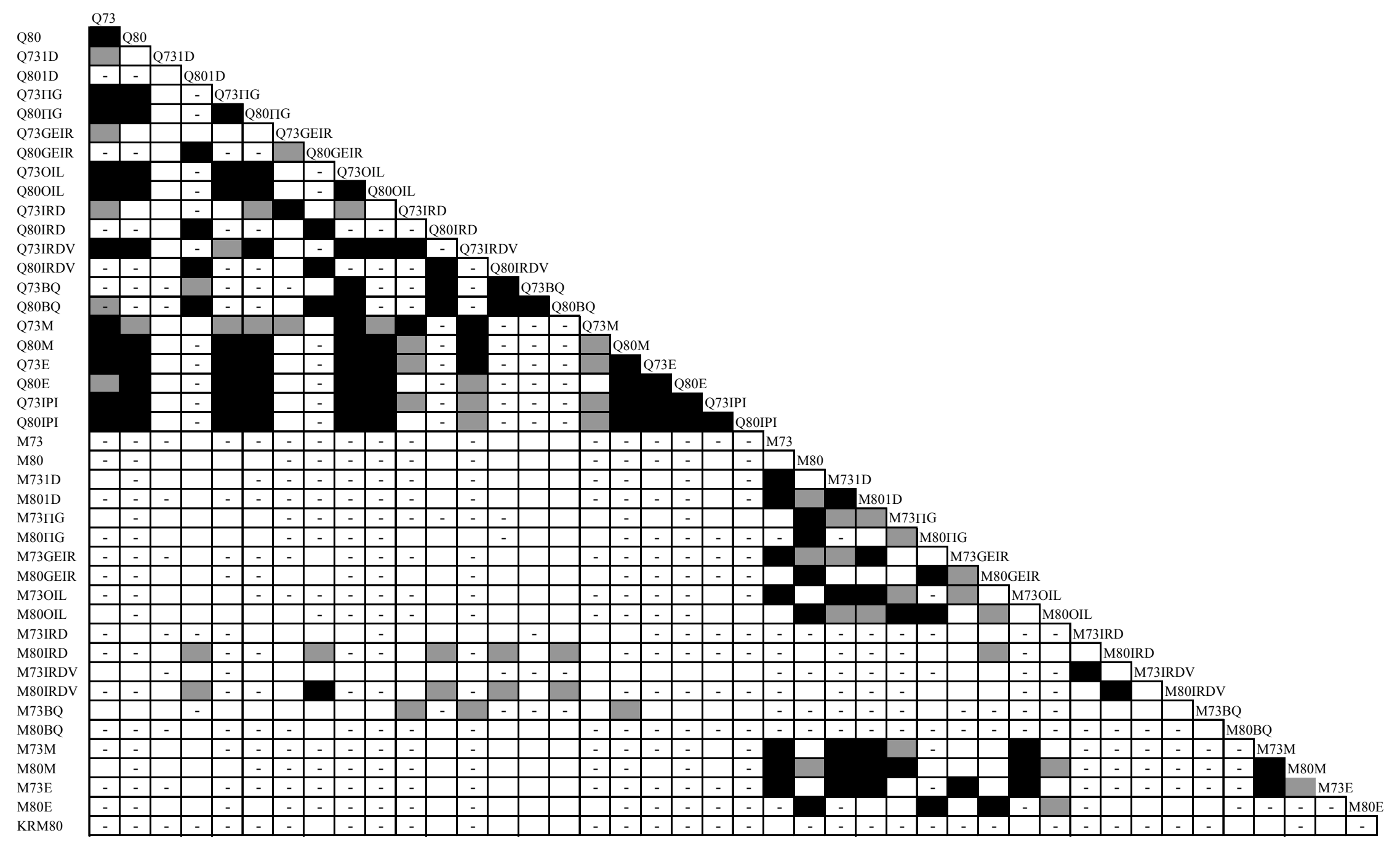


Figure 4. Correlations of the peak inflation effect

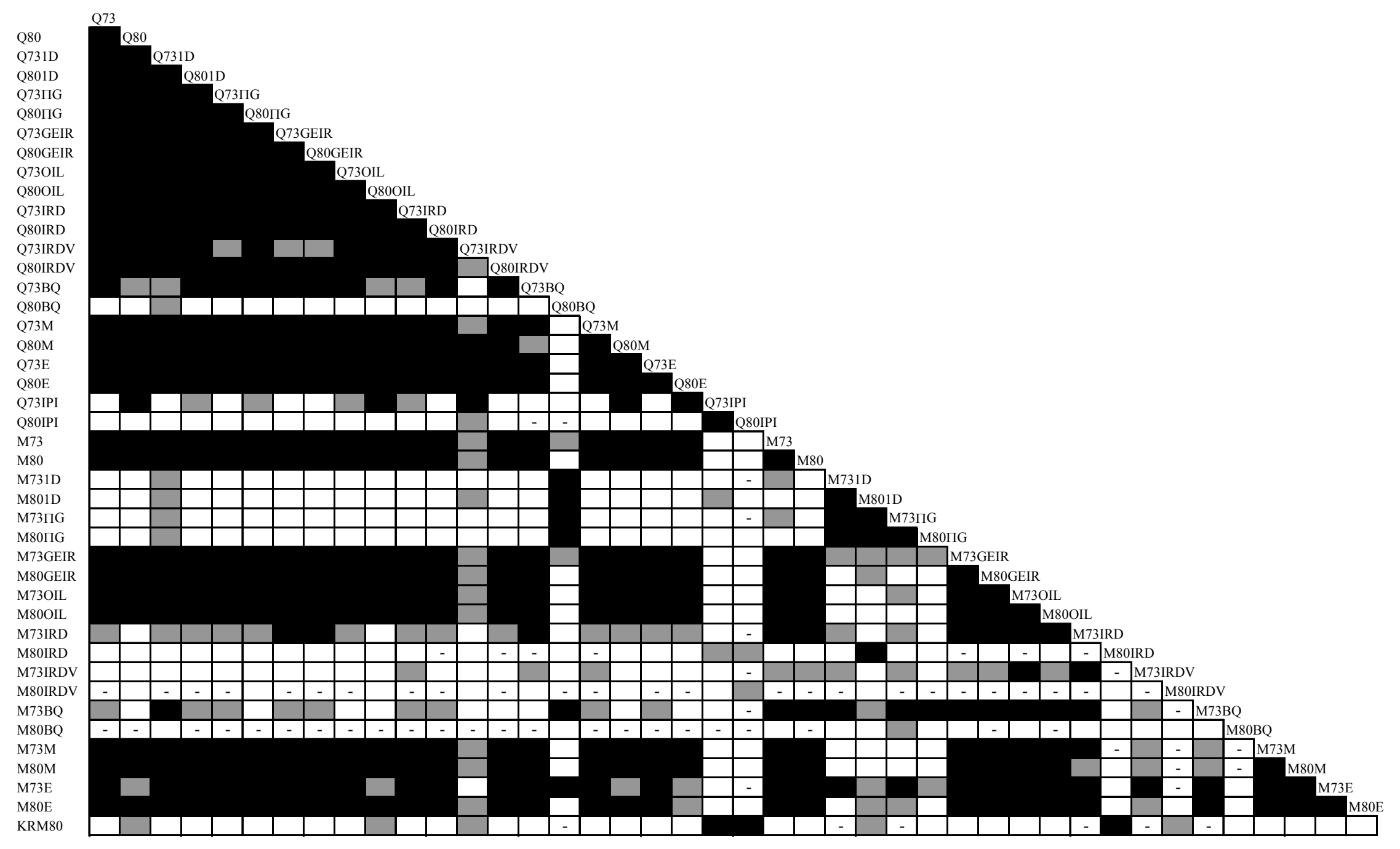


Figure 5: Correlations of the timing of the peak output effect

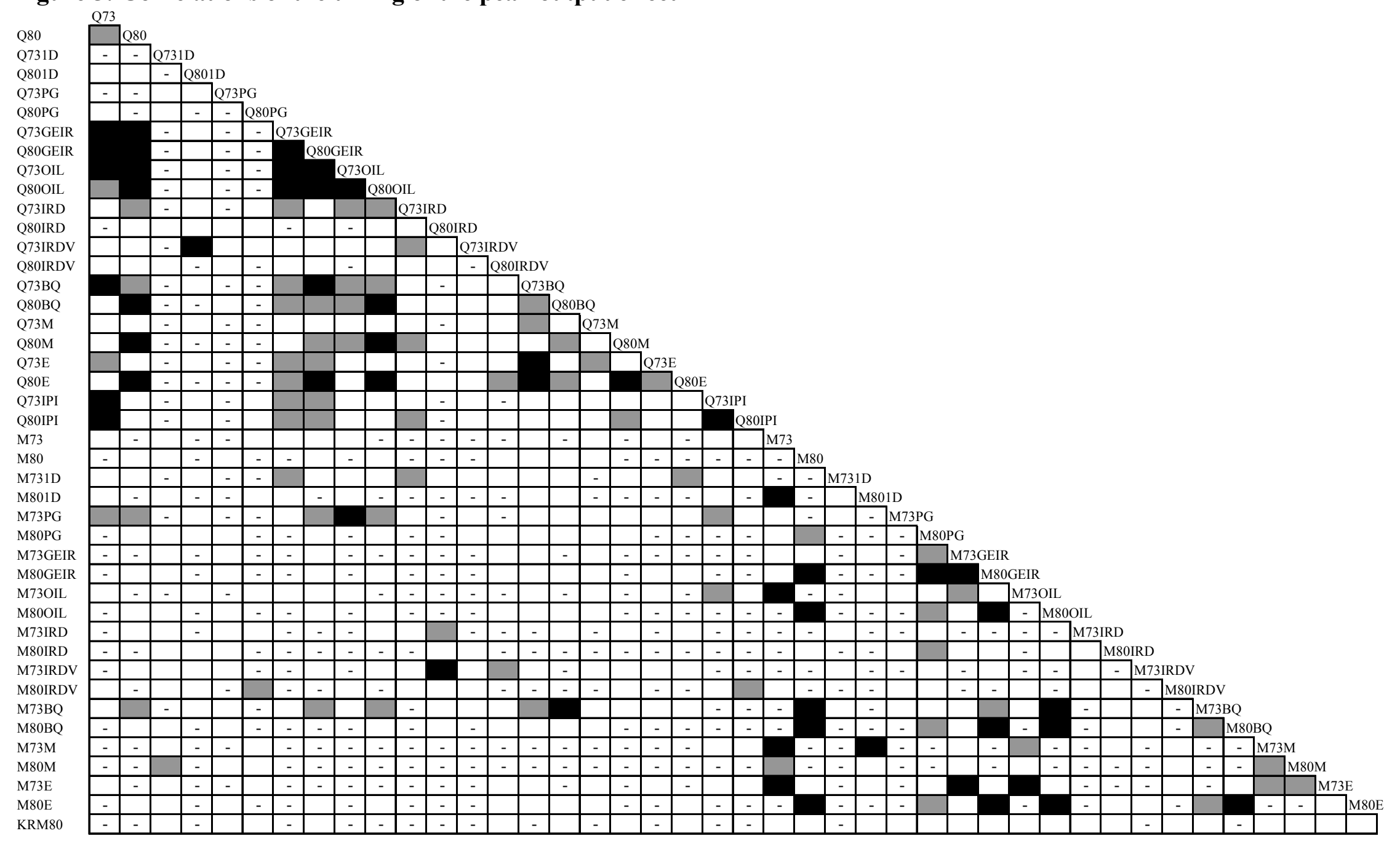


Figure 6: Correlations of the summed output effects

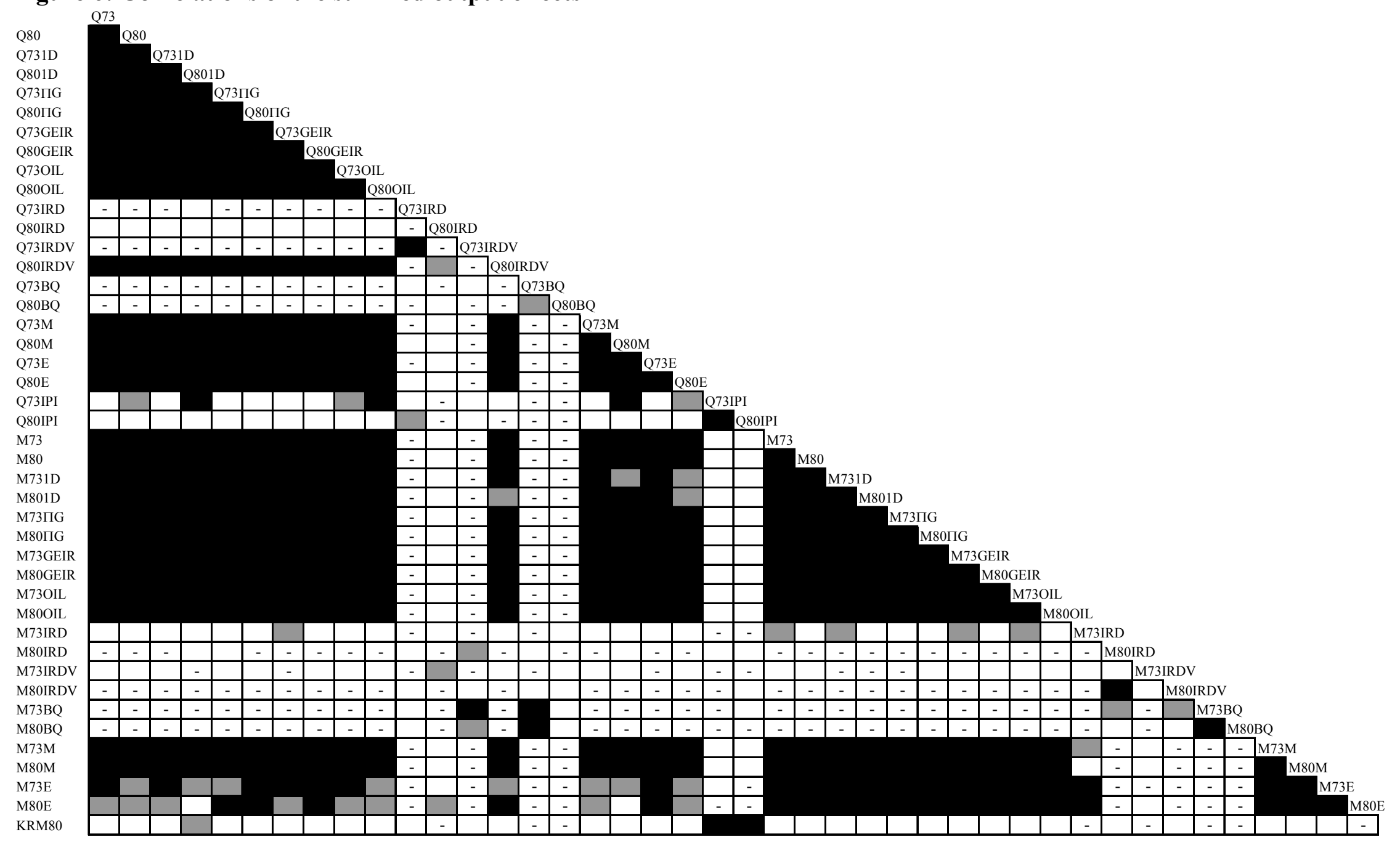




\title{
CESifo Working Paper Series
}

\author{
(for full list see www.cesifo.de)
}

1265 Hans-Werner Sinn, Migration, Social Standards and Replacement Incomes. How to Protect Low-income Workers in the Industrialized Countries against the Forces of Globalization and Market Integration, August 2004

1266 Wolfgang Leininger, Fending off one Means Fending off all: Evolutionary Stability in Submodular Games, August 2004

1267 Antoine Bommier and Bertrand Villeneuve, Risk Aversion and the Value of Risk to Life, September 2004

1268 Harrie A. A. Verbon and Lex Meijdam, Too Many Migrants, Too Few Services: A Model of Decision-making on Immigration and Integration with Cultural Distance, September 2004

1269 Thomas Eichner and Rüdiger Pethig, Economic Land Use, Ecosystem Services and Microfounded Species Dynamics, September 2004

1270 Federico Revelli, Performance Rating and Yardstick Competition in Social Service Provision, September 2004

1271 Gerhard O. Orosel and Klaus G. Zauner, Vertical Product Differentiation When Quality is Unobservable to Buyers, September 2004

1272 Christoph Böhringer, Stefan Boeters, and Michael Feil, Taxation and Unemployment: An Applied General Equilibrium Approach, September 2004

1273 Assaf Razin and Efraim Sadka, Welfare Migration: Is the Net Fiscal Burden a Good Measure of its Economics Impact on the Welfare of the Native-Born Population?, September 2004

1274 Tomer Blumkin and Volker Grossmann, Ideological Polarization, Sticky Information, and Policy Reforms, September 2004

1275 Katherine Baicker and Nora Gordon, The Effect of Mandated State Education Spending on Total Local Resources, September 2004

1276 Gabriel J. Felbermayr and Wilhelm Kohler, Exploring the Intensive and Extensive Margins of World Trade, September 2004

1277 John Burbidge, Katherine Cuff and John Leach, Capital Tax Competition with Heterogeneous Firms and Agglomeration Effects, September 2004

1278 Joern-Steffen Pischke, Labor Market Institutions, Wages and Investment, September 2004 
1279 Josef Falkinger and Volker Grossmann, Institutions and Development: The Interaction between Trade Regime and Political System, September 2004

1280 Paolo Surico, Inflation Targeting and Nonlinear Policy Rules: The Case of Asymmetric Preferences, September 2004

1281 Ayal Kimhi, Growth, Inequality and Labor Markets in LDCs: A Survey, September 2004

1282 Robert Dur and Amihai Glazer, Optimal Incentive Contracts for a Worker who Envies his Boss, September 2004

1283 Klaus Abberger, Nonparametric Regression and the Detection of Turning Points in the Ifo Business Climate, September 2004

1284 Werner Güth and Rupert Sausgruber, Tax Morale and Optimal Taxation, September 2004

1285 Luis H. R. Alvarez and Erkki Koskela, Does Risk Aversion Accelerate Optimal Forest Rotation under Uncertainty?, September 2004

1286 Giorgio Brunello and Maria De Paola, Market Failures and the Under-Provision of Training, September 2004

1287 Sanjeev Goyal, Marco van der Leij and José Luis Moraga-González, Economics: An Emerging Small World?, September 2004

1288 Sandro Maffei, Nikolai Raabe and Heinrich W. Ursprung, Political Repression and Child Labor: Theory and Empirical Evidence, September 2004

1289 Georg Götz and Klaus Gugler, Market Concentration and Product Variety under Spatial Competition: Evidence from Retail Gasoline, September 2004

1290 Jonathan Temple and Ludger Wößmann, Dualism and Cross-Country Growth Regressions, September 2004

1291 Ravi Kanbur, Jukka Pirttilä and Matti Tuomala, Non-Welfarist Optimal Taxation and Behavioral Public Economics, October 2004

1292 Maarten C. W. Janssen, José Luis Moraga-González and Matthijs R. Wildenbeest, Consumer Search and Oligopolistic Pricing: An Empirical Investigation, October 2004

1293 Kira Börner and Christa Hainz, The Political Economy of Corruption and the Role of Financial Institutions, October 2004

1294 Christoph A. Schaltegger and Lars P. Feld, Do Large Cabinets Favor Large Governments? Evidence from Swiss Sub-Federal Jurisdictions, October 2004

1295 Marc-Andreas Mündler, The Existence of Informationally Efficient Markets When Individuals Are Rational, October 2004 
1296 Hendrik Jürges, Wolfram F. Richter and Kerstin Schneider, Teacher Quality and Incentives: Theoretical and Empirical Effects of Standards on Teacher Quality, October 2004

1297 David S. Evans and Michael Salinger, An Empirical Analysis of Bundling and Tying: Over-the-Counter Pain Relief and Cold Medicines, October 2004

1298 Gershon Ben-Shakhar, Gary Bornstein, Astrid Hopfensitz and Frans van Winden, Reciprocity and Emotions: Arousal, Self-Reports, and Expectations, October 2004

1299 B. Zorina Khan and Kenneth L. Sokoloff, Institutions and Technological Innovation During Early Economic Growth: Evidence from the Great Inventors of the United States, 1790 - 1930, October 2004

1300 Piero Gottardi and Roberto Serrano, Market Power and Information Revelation in Dynamic Trading, October 2004

1301 Alan V. Deardorff, Who Makes the Rules of Globalization?, October 2004

1302 Sheilagh Ogilvie, The Use and Abuse of Trust: Social Capital and its Deployment by Early Modern Guilds, October 2004

1303 Mario Jametti and Thomas von Ungern-Sternberg, Disaster Insurance or a Disastrous Insurance - Natural Disaster Insurance in France, October 2004

1304 Pieter A. Gautier and José Luis Moraga-González, Strategic Wage Setting and Coordination Frictions with Multiple Applications, October 2004

1305 Julia Darby, Anton Muscatelli and Graeme Roy, Fiscal Federalism, Fiscal Consolidations and Cuts in Central Government Grants: Evidence from an Event Study, October 2004

1306 Michael Waldman, Antitrust Perspectives for Durable-Goods Markets, October 2004

1307 Josef Honerkamp, Stefan Moog and Bernd Raffelhüschen, Earlier or Later: A General Equilibrium Analysis of Bringing Forward an Already Announced Tax Reform, October 2004

1308 M. Hashem Pesaran, A Pair-Wise Approach to Testing for Output and Growth Convergence, October 2004

1309 John Bishop and Ferran Mane, Educational Reform and Disadvantaged Students: Are They Better Off or Worse Off?, October 2004

1310 Alfredo Schclarek, Consumption and Keynesian Fiscal Policy, October 2004

1311 Wolfram F. Richter, Efficiency Effects of Tax Deductions for Work-Related Expenses, October 2004 
1312 Franco Mariuzzo, Patrick Paul Walsh and Ciara Whelan, EU Merger Control in Differentiated Product Industries, October 2004

1313 Kurt Schmidheiny, Income Segregation and Local Progressive Taxation: Empirical Evidence from Switzerland, October 2004

1314 David S. Evans, Andrei Hagiu and Richard Schmalensee, A Survey of the Economic Role of Software Platforms in Computer-Based Industries, October 2004

1315 Frank Riedel and Elmar Wolfstetter, Immediate Demand Reduction in Simultaneous Ascending Bid Auctions, October 2004

1316 Patricia Crifo and Jean-Louis Rullière, Incentives and Anonymity Principle: Crowding Out Toward Users, October 2004

1317 Attila Ambrus and Rossella Argenziano, Network Markets and Consumers Coordination, October 2004

1318 Margarita Katsimi and Thomas Moutos, Monopoly, Inequality and Redistribution Via the Public Provision of Private Goods, October 2004

1319 Jens Josephson and Karl Wärneryd, Long-Run Selection and the Work Ethic, October 2004

1320 Jan K. Brueckner and Oleg Smirnov, Workings of the Melting Pot: Social Networks and the Evolution of Population Attributes, October 2004

1321 Thomas Fuchs and Ludger Wößmann, Computers and Student Learning: Bivariate and Multivariate Evidence on the Availability and Use of Computers at Home and at School, November 2004

1322 Alberto Bisin, Piero Gottardi and Adriano A. Rampini, Managerial Hedging and Portfolio Monitoring, November 2004

1323 Cecilia García-Peñalosa and Jean-François Wen, Redistribution and Occupational Choice in a Schumpeterian Growth Model, November 2004

1324 William Martin and Robert Rowthorn, Will Stability Last?, November 2004

1325 Jianpei Li and Elmar Wolfstetter, Partnership Dissolution, Complementarity, and Investment Incentives, November 2004

1326 Hans Fehr, Sabine Jokisch and Laurence J. Kotlikoff, Fertility, Mortality, and the Developed World's Demographic Transition, November 2004

1327 Adam Elbourne and Jakob de Haan, Asymmetric Monetary Transmission in EMU: The Robustness of VAR Conclusions and Cecchetti's Legal Family Theory, November 2004 